\title{
A Novel ICT Framework for Sustainable Development Goals
}

\author{
Olivera Kostoska ${ }^{1,2, * \mathbb{C}}$ and Ljupco Kocarev $2,3, * \mathbb{C}$ \\ 1 Faculty of Economics-Prilep, “St. Kliment Ohridski” University, 7000 Bitola, Macedonia \\ 2 Macedonian Academy of Sciences and Arts, 1000 Skopje, Macedonia \\ 3 Faculty of Computer Science and Engineering, Ss. Cyril and Methodius University, 1000 Skopje, Macedonia \\ * Correspondence: olivera.kostoska@uklo.edu.mk (O.K.); lkocarev@manu.edu.mk (L.K.)
}

Received: 15 January 2019; Accepted: 22 March 2019; Published: 2 April 2019

\begin{abstract}
Sustainable development is critical to ensure the future of humanity. Therefore, the assessment and governance of sustainability becomes a central challenge our society is facing. This paper provides a novel ICT framework for addressing sustainable development goals. It is characterized by both local and global considerations, in the context of economic, ecological, and social aspects of sustainable development. The framework consists of three modules: data module, sustainability module, and governance module. Data module integrates data from several sources, processes data, infers knowledge, and transforms data into understandable information and knowledge. The second module implements SDGs at the level of municipality/city, ensures ranking of locally transformed SDGs to arrange them in line with the values and needs of the local communities, and proposes an integrated approach in modeling the social-ecological systems. By implementing governance theories, the governance module permits an effective citizen engagement in governance of SDGs. The ICT framework addresses short-term and long-term SDGs and allows for the vertical and horizontal linkages among diverse stakeholders, as well as for their contributions to the nested rule structures employed at operational, collective, and constitutional levels. Thus, the framework we provide here ensures a paradigm shift in approaching SDGs for the advancement of our society.
\end{abstract}

Keywords: sustainable development goals; ICT framework; governance science; sustainability science; data science; digital democracy

\section{Introduction}

At the UN Sustainable Development Summit in September 2015, the world leaders adopted a new 2030 Agenda for Sustainable Development which is "a plan of action for people, planet and prosperity" designed to "shift the world onto a sustainable and resilient path" [1]. At the heart of this universal, integrated and transformative Agenda are the 17 Sustainable Development Goals (SDGs) (Figure 1 depicts all 17 goals arranged into three pillars: social, environmental, and economic), 169 associated targets, and 232 indicators. Total number of indicators listed in the global indicator framework of SDG is 244 . However, as nine indicators repeat under two or three different targets, the total number reduces to 232 .

Far more ambitious than the Millennium Development Goals (MDGs), the new SDGs framework contains several bold objectives to be achieved by the year 2030, including the end of poverty (SDG 1), and hunger (SDG 2), good health and well-being for all (SDG 3), universal secondary education (SDG 4), access to affordable, sustainable and modern energy (SDG 7), sustainable cities and communities (SDG 11), actions to combat climate change (SDG 13), protecting and promoting sustainable use of the oceans, seas and marine (SDG 14) and of the terrestrial ecosystems (SDG 15) [2]. The SDGs, otherwise known as the Global Goals, are integrated (and indivisible) and create balance between 
the three facets (economic, social, and environmental) of sustainable development. They are unique in that they call for action by the whole world (developed and developing countries alike) and their constituents making them bound to perform their level best to attain a considerable reduction of inequalities. Acknowledging that ending poverty is closely related to strategies that create economic growth and address a range of social and environmental needs, the Goals comprise opportunities for all stakeholders (national governments, transnational companies, and civil society) to contribute to a more sustainable world. The 2030 Agenda also calls for a deeper participation and engagement of the private sector and partnerships to support governments to harness all the tools necessary to implement and deliver the required changes.
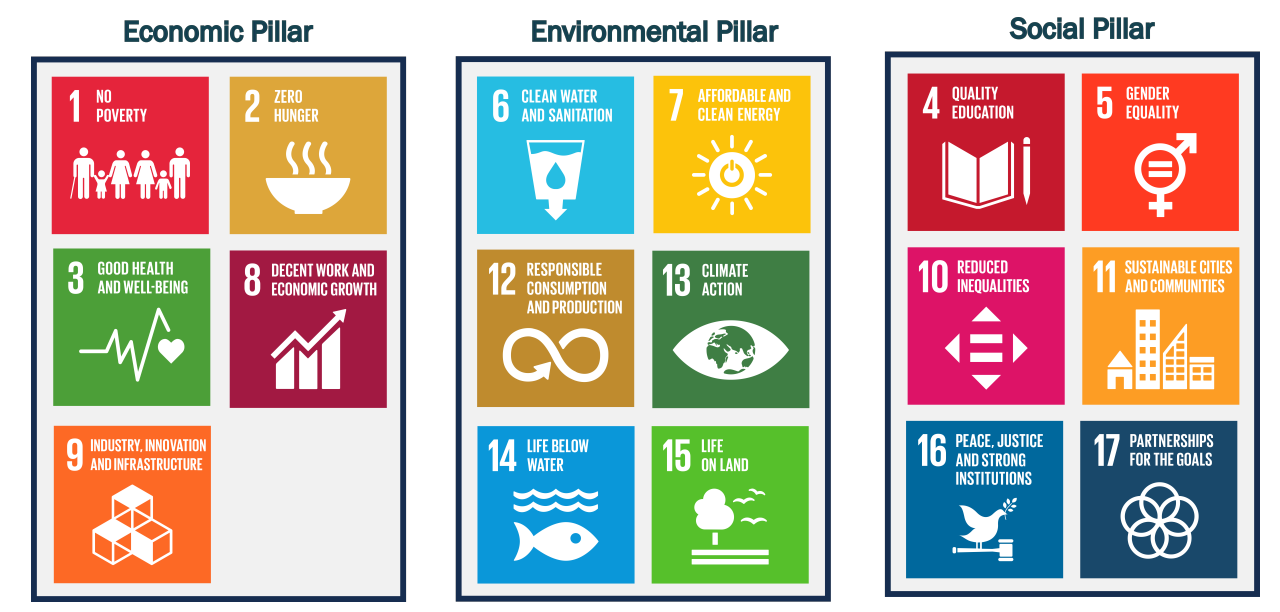

Figure 1. 17 sustainable development goals clustered into three pillars: economic, environmental, and social.

Addressing these global 'stretch' goals, however, would require a transformation of societies that is faster and far more substantive than in the past-the rate of change that a Business-As-Usual (BAU) approach cannot deliver [3]. Information and Communications Technology (ICT), and especially mobile broadband, is an essential infrastructure platform for the SDGs and a principal acceleration technology that can get societies away from the BAU trajectory. The future developments in ICTs, including the Internet of Things (IoT), advanced robotics, artificial intelligence, big data, 3-D printing, and others, will make tools available for all new and extraordinary improvements in healthcare and education services, energy, and environmental protection. The UN Broadband Commission for Sustainable Development has also put emphasis on the pivotal role that ICT can play in providing integrated, innovative and cross-sectoral sustainable development results [4]. Aside from delivering connectivity, innovation, and productivity, ICT can also reinforce flexibility of the crucial infrastructure and help to succeed in dealing with the social and economic exclusion [4]. Mobile broadband provides overwhelming gains in accessibility, scalability and affordability that can permit countries to close numerous development gaps at the highest speed ever recorded, without the outlay of traditional infrastructure [5]. While none of the 17 SDGs is particularly about ICT and only several targets refer to ICT and technology, the 2030 Agenda for Sustainable Development fundamentally recognizes that the scope of ICT and global interconnectedness has a huge potential to speed up the human progress, to bridge over the digital divide and to create knowledge societies [1]. ICTs play the role of catalyst in all three cornerstones of sustainable development (economic development, social inclusion, and environmental protection), but they are also critical for attaining all SDGs. To that end, the effective implementation of the World Summit on the Information Society (WSIS) Action Lines can help accelerate the achievement of the SDGs. The WSIS-SDGs Matrix, developed by the UN Action line Facilitators, provides rationale and clearly indicates the linkage between each Action line and the SDGs [6]. 
Thanks to Moore's Law, ICT has actually brought about the Information Age, the fifth great technological age since the beginning of the Industrial Revolution. Each of these five ages, the so-called Kondratieff Waves, has accelerated growth and development of the global economy: steam engine and textile industry (1780-1830), railway and steel industries (1830-1880), electricity and chemistry (1880-1930), automobiles and petrochemicals (1930-1970), and information (1970-present) [7,8]. ICT has prompted global economic growth for at least 30 years, but its utmost gains are yet to be attained. In other words, the Information Age is expected to clear the way for the Age of Sustainable Development, i.e., the (sixth) surge of sustainable technologies that will make the SDGs as successful as possible $[8,9]$. The ICT revolution is of course not based on one technology, but represents an interaction of fundamental technologies, including computer design, digital wireless, statistical multiplexing, encryption, satellite communications, machine learning, to name but a few. No less important is the use of ICTs. Taking into account that these technologies have a major role to play in creating, storing and transmitting information and in reducing the market failures associated with information asymmetries [10-12], ICT has an indirect effect on productivity which is mainly visible in sectors using them [13]. That is to say, "ICT are enablers of product, process and organizational innovation in ICT-using sectors, and this, according to Bresnahan and Trajtenberg [14], qualifies them as General Purpose Technologies (GPT): technologies that are pervasive-i.e., can be applied to several production processes-allow continuous improvements and experimentation and facilitates innovation in using sectors (through co-inventions)" [15]. The influences are so much extensive, with a huge number of complementarities (as reported by Bresnahan and Trajtenberg), that ICT has properly been viewed as generating an overall social transformation, the so-called Networked Society [3]. In a nutshell, ICT has the capacity to produce a digital transformation of the entire society and a huge potential to raise the rate of diffusion of variety of technologies, applications and platforms across the economy. Yet it is noteworthy that there has been an emergence of literature all pointing out that ICTs are also subject to significant rebound effects of all kinds (energy, time, and knowledge-related), especially because they are GPT that can produce high resource savings all over the entire economy and society [16,17]. Rebound effects are actually the "negative side effects of efficiency policies and strategies that ended up taking back the environmental gains they had permitted" [16]. The expected gain "rebounds" as a result of behavioral and systemic reactions in a complex economy [18]. In general terms, the efficiency strategy should not depend solely on technological change, but "must always be accompanied by a sufficiency strategy" [19]. Other authors have also provided reasons for such behavioral changes on the consumer side [20-23]. All things considered, it is necessary to raise the general awareness of the rebound effects [24], including the limits of the idea, particularly at the macro level.

Achieving the SDGs, however, calls for multi-sectoral partnerships, and governments, academic institutions, companies and people need to work together and prepare themselves for this ICT-empowered transformation to a Networked Society. While private-sector applications of ICT have ascended, many of the challenges of sustainable development (education, health, infrastructure, and environmental sustainability) call for an intense role on the part of the public sector and those responsible for policy making. This, in turn, places the focus on institutions, which are critical for the success or failure of development. Governments are responsible for making sure that public-sector organizations, institutions and regulatory frameworks have changed enough to support the ICT-empowered transformation. Institutional quality will increasingly be determined by the extent to which entities adopt innovative solutions to enable the delivery, transparency, openness and efficiency of the public services. Against the background of the ambitious global development agenda, demanding global challenges and ICT-enabled transformation, policy makers are required not only to behave as socio-economic accelerators, but also to recruit the nationwide collective action for transformation. Governments are responsible for policies and legal frameworks that regulate the deployment of ICT. They monitor the land use, distribution of spectrum, right-of-way for fiber and other infrastructure, and the tax and regulatory policies that, in the end, will decide the speed of rollout of the ICT backbone and access networks, the service providers, and the acceptance of ICT-based 
solutions in the vital public services [3]. However, if not used effectively, ICTs may actually make things worse. While there is a positive effect in terms of driving economic growth, increasing efficiency, and extending markets, ICTs may also contribute to economic and social problems by putting emphasis on equity divides and increasing the market power of dominant firms. Hence, managing the growth of ICTs to make the most of the net social benefits is a complex challenge. The achievement of the potential benefits of ICTs for SDGs depends heavily on the existence of complementary elements ("analog" complements for the digital economy). First, the basic ICT infrastructure needs to be in place. Nowadays, this entails a universal access to mobile broadband services, and requires that access be available, affordable, and adopted [25]. ICT infrastructure alone, however, is not sufficient to reach the benefits of ICTs. Consumers and workers must have an access to applications and devices, as well as the necessary skills to use ICTs effectively. Imbalances in access to ICTs and the required complementary assets can lead to unbalanced growth and increased economic and social disparities. At best, the poor attention to complementary assets will render the ICT investment ineffective. At worst, ICTs may actually damage the achievement of SDGs. For example, Communication Technology accounted for around $14 \%$ of the global electricity usage (worst-case scenario for 2010) [26], and with the growth of its intensity worldwide, Communication Technology is expected (viz. in the expected-case scenario) to consume up to $21 \%$ in 2030 (or as much as $51 \%$ for the worst-case scenario) unless it becomes more electricity efficient [26]. ICTs will need to meet this challenge if they do not want to become an important contributor to climate change and sustainability problems in their own right. Along with the possibility to become more energy efficient themselves, ICTs are also expected to play a crucial role in making sure that all sectors of the economy are more energy efficient-an indispensable requirement to achieve the global aspirations for improving quality of life in a sustainable manner. Moreover, ICTs and the advances of global Internet impose the necessity to give a proper attention to cybersecurity and the challenges that unreliable or insecure ICT infrastructure and services pose for social and political sustainability. Finally, and perhaps the most important "if the ICT-enabled economic growth proceeds without complementary improvements in the sustainability with which we use other resources, the expansion in global consumption of resources from water to energy will pose an even greater challenge" [25]. In other words, ICTs have the potential to increase the threats to our environment, security, and the sense of well-being that may not be directly the result of ICTs, but that are almost certainly deteriorated by these technologies.

These various arguments all suggest the reasons and requirements to establish a proper framework in place, so that ICT can support delivering a change the world needs to achieve the Global Goals and make sure no one is left behind. This paper aims at proposing an ICT framework for both addressing the complexity of SDGs and providing knowledge for building ICT platforms. We are aware that there is a critical reflection on the frameworks that are based on the so called "three pillars" and the approaches to find a "balance" between the environment, economy, and society. For example, Pouri and Hilty look at "the economic system as a part of human society and human society as a phenomenon that has become possible due to the biological processes on earth which have been reliably carrying it so far" [27]. The LES model, built up to structure the impact of ICT on sustainability, was actually based on this point of view [28]. Nevertheless, we intentionally use the "three pillars" or "dimensions" of sustainability because (alongside the environmental and economic sustainability) we would like to lay stress on the sound public policies that support healthy governance systems (social and political sustainability), as ICTs will progressively change the governance and delivery of every single type of public services. With this in mind, we propose four design principles intended to (1) configure the basic building blocks of the ICT framework provided here (data module, sustainability module, and governance module), (2) implement coordinated efforts of various stakeholders at different spatial, temporal, and decision-making scales, (3) allow various governance theories to be implemented in the framework, and (4) provide incentives for individuals to take a part in the decision-making process. Hence, this work aims to contribute new knowledge to recent literature and policy discussions on the potential of ICT to offer an extraordinary platform for achieving the SDGs. 
The rest of the paper is organized as follows. Section 2 deals with the concept of sustainability according to different streams of thought, examines the existing research initiatives that have addressed SDGs from different perspectives, and provides a plan to design the paper. Section 3 describes the fundamentals (governance science, sustainability science, data science, and digital democracy) for addressing sustainable development. Section 4 refers to the four design principles we propose for the ICT framework. Section 5 depicts the ICT framework for SDGs that is made up of three modules: data module, sustainability module, and governance module. Section 6 concludes and makes recommendations.

\section{Background of the Problem and Our Contribution}

\subsection{A Changing-Discourse Perspective on Sustainability}

The rising concerns about environmental and climate change over the past few years, as well as the problems of poverty and disparities have placed sustainable development under the spotlight. Policy makers, institutions and cross-country initiatives (e.g., the UN Sustainable Development Solutions Network —SDSN_operating since 2012), together with practitioners and academics [29] have all made the interest in social and environmental sustainability to increase rapidly. Nevertheless, the vagueness and ubiquity of the concept [30] made the actual implementation of sustainability limited and enabled various discourses (environmental, social, and business) to emerge over time. In an effort to go beyond the meagre rhetoric of sustainability and follow an actual quest for sustainable development, we believe that the concept (and its dimensions-financial, social, and environmental) need to be precisely defined, and an integrated approach to the idea of sustainability needs to be adopted [31]. Sustainable development shall not be accomplished over separated initiatives, but calls for integrated efforts at different points, covering environmental, social and financial prospects. In point of fact "any foreseeable sustainable state will be the result of interactions between organizations, individuals, societies and states" [32].

Although the multidimensionality of sustainability has never been put aside, the concept has often been considered an environmental issue [33]. At this point, one of the leading moves was the 1972 United Nations Conference on Human Environment held in Stockholm, which acted as a mechanism for establishing a number of national environmental protection agencies and, more importantly, for developing the UN Environmental Programme (UNEP). The latter emphasized the importance of eco-development [34] and recovered the notion of sustainable yield [35] in its definition of eco-development. In 1987, the final report of the World Commission on Environment and Development (WCED), entitled Our Common Future (or Brundtland Report), provided the widely-held definition on sustainable development, viz. a "development that meets the needs of the present without compromising the ability of future generations to meet their own needs". Perhaps more important, however, is the 1992 UN Conference on Environment and Development (UNCED), also known as the Rio Earth Summit, which resulted in the following key documents: the Rio Declaration on Environment and Development, the Statement of Forest Principles and Agenda 21. Although the latter provided advice and good practice for achieving sustainable development, the 1997 Kyoto Conference on Climate Change saw an emergence of poor progress towards Agenda 21 goals.

Whilst the environmental discourse was evolving in the sustainable development discussions, neither the social prospects were abandoned. In point of fact, WCED draws attention to inter-generational equity (viz. reconciling the requirements of the existing and the generations to come) and thus highlighted social aspects, particularly the critical facets of social equity, such as social justice, distributive justice and equality of conditions [36]. From the UN's point of view, after the Kyoto Conference on Climate Change, the Millennium Development Goals (MDGs) represent a significant step forward in addressing social concerns. The MDGs were the eight goals that all UN member states had come to an agreement to achieve by the year 2015. They were created out of the $2000 \mathrm{UN}$ Millennium Declaration that committed the world leaders to eradicate poverty and hunger, combat 
illiteracy, diseases and child mortality, provide gender equality and environmental sustainability. Subsequently, the negotiations at the 2002 Johannesburg World Summit on Sustainable Development (WSSD) "demonstrated a major shift in the perception of sustainable development-away from environmental issues toward social and economic development" [33]. This shift, which was strongly influenced by the MDGs and driven by the requirements of developing countries, represents an illustration of how sustainable development has been dragged in multiple directions over its (more than two decades) long history. By integrating the MDGs with additional socio-economic aspects, the WSSD "did make a constructive change by focusing considerably more attention on development issues" [33].

In 2012, a 20-year follow-up to the 1992 Earth Summit was held in the form of another UN Conference on Sustainable Development (UNCSD) which took place in Rio de Janeiro, Brazil. The Conference, also known as Rio+20, was intended to address novel and emergent challenges, safeguard a renewed political commitment for sustainable development, and evaluate the development and implementation problems in meeting the prior commitments. In Rio, member states decided, among others, to start a process to develop a set of Sustainable Development Goals (SDGs), which will build upon the MDGs and converge with the post 2015 development agenda. In January 2015, the negotiation process on the post-2015 development agenda began, which has ended up in the subsequent adoption of the 2030 Agenda for Sustainable Development (with 17 SDGs at its core) in September 2015. In essence, the main reasons for poverty and universal demand for development that works for all. Along with the persistent development needs, such as poverty eradication, education, health, food security and nutrition, they set forth a variety of interrelated economic, social, and environmental aims including more peaceful and inclusive societies. In point of fact, the Rio +20 repeated once again the many different features of sustainability. The Conference resulted in a focused political outcome document- "The Future We Want"- which makes a reference to the three aspects of sustainable development (economic, social, and environmental), but also to good governance as a key element for sustainable development. This idea is also held by the Sustainable Development Solutions Network, which considers good governance (including peace and security) to be critical for sustainability. Nevertheless, global governance is still confronting (facing) two major obstacles. First, the global governance arena is embedded in economic structures and regimes, in which market power has been translated into political power. Even Global Redesign Initiative, as an attempt by the World Economic Forum to reshape the agenda and formulate a new system of global governance, is highly influenced by the most important and powerful businesses. Second, global governance institutions, created in the last century, have not been adapted to the digital and networked world. Although global governance institutions are created to steer social processes at the international level through international laws and norms, so far they have not properly addressed sustainable development. Nevertheless, there are few studies across a range of academic disciplines which have addressed the global environmental challenges, such as global environmental governance [37-39] and international environmental law [40-42]. Several reforms of the global governance institutions have also been proposed [43], including those grounded on the concepts of global systems science [43] and complex adaptive systems [44].

In essence, the 2030 Agenda addresses holistically environmental, social, and economic concerns, aiming to transform the purely economic model of prosperity of our society to an integrated and sustainable model of prosperity. The success of the 2030 Agenda, however, depends on its implementation. Means of implementations have been outlined in [1] stressing that "quality, accessible, timely and reliable disaggregated data" are needed "to help with the measurement of progress and to ensure that no one is left behind" [1]. The 2030 Agenda indicators are essential for "the measurement of progress" and "key to decision-making" [1]. In point of fact, indicators are central to many initiatives for both generating knowledge and communicating about complex phenomena. Similarly, experts are placed in a better position to measure an otherwise immeasurable entity by properly selecting and estimating a predetermined group of quantified indicators that approximate the crucial components of 
a certain concept [45]. The use of indicators in this way could be found in sustainability research [46] where they can operate as an analytical structure that mediates between the complex (and difficult to study) concept of sustainability, and the analytical tools appropriate for exploring the complex systems. "While indicators remove contextual information and obscure the process through which this happens, they also force a clarity and rigour that exposes political priorities and beliefs" [47]. This is clearly visible in SDGs, which often refer to such wide concepts that are widely held by the global society and consistent with the national sustainability initiatives. Nevertheless, the SDG indicators disclose very specific perspectives on these issues, some of which are in direct conflict with national perspectives. For example, the Goal 8 intends to promote such a worthy purpose that few would disagree with, i.e., "decent work". Nevertheless, the SDG indicators disclose very specific angles on these issues, some of which are in direct conflict with national prospects [48]. Some authors use the concepts of job satisfaction or fulfillment [49], yet there are no indicators available to reflect these ideas of "decent work". In short, for some indicators one needs "to operationalize the Sustainable Development Goals' targets and evaluate the indicators' relevance, the characteristic of utmost importance among the indicators' quality traits" [50]. Other indicators are able to achieve their goal of helping to make the SDGs relevant and useful. For example, in a recent study [51], researchers have created an overall health-related SDG index by considering the performance of a given country across all of the 37 health-related SDG indicators. Finally, the SDG indicators may also permit a quantified form of analysis that can improve our understanding of how the broader targets may be achieved (e.g., in the use of models) [47]. The SDGs work in highly complex, non-linear systems which are difficult to examine without models [52]. Indicators are critical because they provide a mechanism for comparing the model, theory and reality.

\subsection{Brief Insights from the SDGs-Related Literature}

The use of the transformational power of ICTs to develop more sustainable patterns of production and consumption is well documented in the literature that is widely dispersed among different journals, book chapters and conference proceedings [see for example, the international conference on ICT for Sustainability (ICT4S); or the three main conference series for the development of Environmental Informatics-Environmental Informatics (EnviroInfo), International Symposium on Environmental Software Systems (ISESS), and the International Conference on Information Technologies in Environmental Engineering (ITEE)]. However, we make no attempt here to summarize the existing interdisciplinary research fields related to ICT for Sustainability, including Environmental Informatics, Computational Sustainability, Sustainable HCI, and Green ICT (see for example, Hilty and Aebischer [28] for the fundamental ideas and methods of ICT for Sustainability; Hilty and Lohmann [53] for the major contributions presenting conceptual frameworks to structure this field of research). Rather, since the focus of this paper is to propose a novel ICT framework (based on a range of distinct principles) to address the complexity of SDGs, this section will discuss the most prominent actions and rethinks that have been employed in the literature to study the phenomenon from different perspectives. Tjoa and Tjoa [54] provide an overview of the selected few articles in the area of ICT and SDGs, and appeal to all scientists, IT-professionals and their organizations to take a holistic approach to all ICT-related activities and projects and to always include and monitor the effects of their work on SDGs. Costanza et al. describe a novel index called Sustainable Wellbeing Index and propose to connect the SDGs with this index by considering "a comprehensive systems dynamics model that can track stocks and flows and make projections into the future under different policy scenarios" [55]. Janowski's editorial [56] concludes that Digital Government should play a key role in implementing SDGs, but the gap between aspirations (SDGs) and capacity (Digital Government) is affecting the majority of the UN Member States. Holden, Linnerud, and Banister [57] discuss a model for sustainable development which, in addition to providing economic, social, and environmental balance, establishes constraints on humans' social and economic activities. Allen, Metternicht, and Wiedmann [58], by reviewing the national observations in implementing the SDGs in 26 countries, 
conclude that although some initial progress is evident, nevertheless, open questions regarding the assessment of interlinkages, trade-offs and synergies between sustainable development targets are yet to be addressed. Wu et al. [59] discuss the influences that ICTs have in addressing the SDGs stressing ICT's role to accelerate the progress and construct knowledge societies. Linkov et al. [60] review various governance strategies for addressing sustainability threats. Campagnolo et al. [61] suggest a methodology for sustainability assessment by aggregating 26 indicators (addressing the SDGs) and stress how much effort each country should undertake to achieve SDGs. Nerini et al. [62] analyze SDG7 by characterizing efforts, in particular their synergies and trade-offs, in achieving SDG7. Zimm, Sperling, and Busch [63] identify sustainability and knowledge gaps in Shared Socio-economic Pathways (SSPs) in relation to the Agenda 2030 SDGs. SSPs, which are used by the Intergovernmental Panel on Climate Change, do not address all SDGs, covering only some of the SDGs (e.g., SDG13).

In view of what has already been said, this paper takes a different perspective to address the overwhelming complexity of SDGs. Strictly speaking, the ICT framework we propose here endorses several novel features (see Figure 2) by aiming at the following:

(a) to combine three disciplines: governance science, sustainability science, and data science, all wrapped together with the concept of digital democracy, and to act as an interactive process reflecting the interactive character of governance;

(b) to increase awareness and understanding of SDGs, through which the societies are steered towards collectively agreed objectives, leading to governance of SDGs on both local and global levels;

(c) to integrate data from several sources at different spatial scales (local, region, state, national, and international), temporal scales (daily, monthly, annual) and decision making scales (individual, group, institution), to infer knowledge and to transform data into understandable knowledge;

(d) to emphasize various governance theories (adaptive governance, network governance, collaborative governance, and accountable governance) and suggest two novel: fair and trustworthy governance, and to ensure actions across many levels and involving actors from multiple sectors;

(e) to allow two-way communications between government and people and effective citizen engagement in addressing SDGs; and

(f) to provide means for ensuring true impacts on SDGs by motivating citizens to participate in addressing SDGs and by enabling those in positions of power to endorse the framework.

The term 'infer knowledge' (or more general term knowledge discovery) is used here narrowly and refers to knowledge extraction from structured and unstructured sources. For the epistemological questions related to the creation and dissemination of knowledge in particular areas of inquiry, we refer the reader to Stanford Encyclopedia of Philosophy [64]. In information science, relationships among data, information, knowledge, and sometimes wisdom are represented hierarchically [65]. However, some scholars have questioned this formulation of the knowledge hierarchy by arguing that wisdom includes also values, ethics, and effectiveness $[66,67]$. 


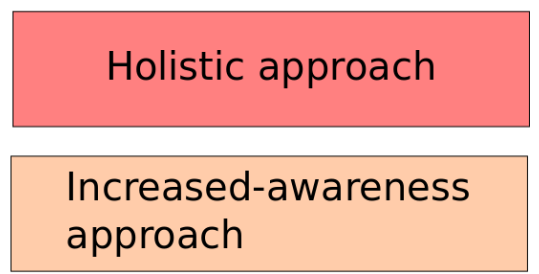

\section{Data-intensive approach}

Governance-enhanced approach

\section{Two-way approach}

\section{Responsible approach}

Figure 2. The ICT framework for SDGs we propose here endorses six novel approaches: holistic approach aiming to integrate three disciplines-governance science, sustainability science, and data science-bonded with the concept of digital democracy; increased-awareness approach ensuring governance of SDGs on both local and global levels; data-intensive approach aiming to implement SDGs by using state-of-the-art machine learning methods at different spatial, temporal, and decision making scales; governance-enhanced approach implementing SDGs by considering various governance theories: adaptive governance, network governance, collaborative governance, accountable governance, fair governance, and trustworthy governance; two-way approach ensuring communications between government and people and effective citizen engagement in addressing SDGs; and responsible approach providing true impacts on SDGs by motivating citizens to participate in addressing SDGs and by enabling those in positions of power to endorse the framework.

\subsection{Research Design}

This section will expose the overall strategy chosen to coherently and logically integrate the different constituents of the paper. We will therefore specify the type of evidence needed to effectively address the research problem and to accurately answer the following research questions:

- RQ1: What research questions regarding ICT for SDGs have already been conducted by combining all three disciplines: governance science, sustainability science, and data science?

- RQ2: How and what ICTs have been adopted for SDGs?

- RQ3: How and what artificial intelligence (AI), machine learning (ML), and other data science methods and tools have been used for SDGs?

Our goal is not only to provide a systematic literature review on ICT for SDGs, but also to identify research gaps for ICT driven enhancement and implementation of SDGs. We conduct a literature review following the PRISMA framework [68] and the suggestions for systematic literature reviews by Siddaway [69] and Bieser and Hilty [70]. We have identified the main search terms based on our research questions, selected the most common scientific literature databases and platforms Web of Science, Scopus, Google Scholar, and Google for the search, found all relevant publications, and selected a number for critical analysis. These publications are further clustered in three groups (data module, sustainability module, and governance module) and subject to analytical discussion in the next sections. As regards the questions RQ1, RQ2, and RQ3, our findings can be summarized as follows:

- Finding 1: The recent development of new governance theories with roots in various disciplines ranging from social sciences to natural sciences, has led to positioning governance science as an independent pillar when addressing SDGs. There is no article that takes a holistic view when addressing SDGs and includes the findings from all three disciplines: governance science, sustainability science, and data science.

- Finding 2: State-of-the-art ICTs such as autonomous things, augmented analytics, AI-driven development, edge and fog computing, digital twins, digital lakes, and immersive technologies have not yet been fully developed and deployed for SDGs. 
- Finding 3: Although AI and ML methods have been increasingly used to track progress toward certain SDGs, nevertheless, the full potential of current state-of-the-art AI/ML methods and tools have not yet been used for improving the implementation of SDGs.

Taken together, the above findings suggest that this paper is actually a first attempt to conceptualize the SDGs (as an ICT-supported phenomenon) in the light of existing discussions in governance science, sustainability science, and data science.

The review analysis has also been used for a "conceptual framework analysis" approach in order to develop an ICT framework for SDGs. A conceptual framework interlinks concepts for ensuring a comprehensive understanding of a phenomenon or phenomena [71], see also [72-74]. The goal of the framework is therefore to indicate the key concepts of a phenomenon, which, when organized and connected, constitute, in our case, an ICT framework for SDGs, that serves as a support or guide for the building of something that expands the framework into a useful product such as an ICT platform. To build a conceptual framework, Jabareen [71] suggests a multi-phase qualitative process consisting of eight phases: (1) Mapping the selected data sources, (2) Extensive reading and categorizing of the selected data, (3) Identifying and naming concepts, (4) Deconstructing and categorizing the concepts, (5) Integrating concepts, (6) Synthesis, resynthesis, and making it all make sense, (7) Validating the conceptual framework, and (8) Rethinking the conceptual framework. Examining all phases including an overview of the literature on SDGs from sustainability, governance, data science, and ICT (the phase 1), reading and clustering the data by discipline and importance to the above three research questions (the phase 2), after reading the selected data and identifying and labeling the concepts (the phase 3), the last phase involves thinking again about the conceptual framework and finalizing the ICT framework for SDGs. The framework consists of a variety of diverse concepts grouped in three modules (data, sustainability, and governance) as discussed in Section 5. In general, the concepts of the data module refer to the statistical, social, and sensor data at three levels of granularity (spatial, temporal, and decision making); the sustainability module consists of the concepts aimed at mapping the SDGs at the local level, ensuing an inclusion of the stakeholders, providing priority ranking of the SDGs, sharing and managing the knowledge, delivering integrated assessment models, and implementing the SDGs at the local level; and finally, the governance module refers to such concepts as the adaptive governance, trustworthy governance, network governance, fair governance, collaborative governance, and accountable governance. The term ICT in our conceptual framework highlights the fact that the framework is shaped by ICT, that is, it is enhanced by digital technologies that master digital representation, computing, and adapting (learning) related to SGDs. As business-systems transition analysis [75-77] and meta-analyses [78,79] reveal that digital technology is the trigger and the catalyst for a fundamental societal transition and economic growth, we think that the ICT framework for SDGs we propose here could offer a basis for improved implementation of SDGs.

\section{Prerequisites for Addressing Sustainable Development}

\subsection{Governance Science}

Governance is widely referred to as "the process of steering society and the economy through collective action and in accordance with common goals" (Torfing et al. [80]). In point of fact, "no single actor has the knowledge, resources and capacities to govern alone in our complex and fragmented societies. Interaction is needed in order to exchange or pool the ideas, resources and competences that are required for the production of desirable outcomes" [81]. Over the years, the preoccupation of much of the research has been with the 'crisis of governance' [82-84] and 'governance failure' $[85,86]$. At least three approaches have emerged in the governance literature to deal with such phenomena [87]. First, there are those who consider the power being diffused among a large number of non-state and global actors [88], with emerging patterns of "networked governance" [89-91] and innovative techniques that facilitate the "governance of complexity" [92]. A second stream of literature analyzes (global) networks and governance practices, and draws attention to the 
emergence of competing "global governance architectures" [91] and new governance techniques, such as "experimental governance" [93], "transitional regulatory governance" [94], "polycentric governance" [95,96], or "participatory governance" [97]. Finally, the third strand, which is highly critical to the idea of 'governance', points to the research problems that the concept itself can produce $[98,99]$. These rising concerns and debates about governance have led to the development of new governance theories with roots in political science, public administration, sociology, economics and law, ecology, complexity science, network science and many other applied fields. The Handbook on Theories of Governance summarizes some of the recent developments in the field and discusses various forms of governance (e.g., network governance, corporate governance, global governance, multi-level governance, democratic governance, adaptive governance, to name but a few), and also emphasizes the interactive dimensions of the concept by defining governance "as the interactive processes through which the society and the economy are steered towards collectively negotiated objectives" [81].

\subsection{Sustainability Science}

Sustainability science is often defined as research in the context of social-ecological systems (SESs) [100-102] also referred to as coupled human-environment systems, coupled human and natural systems, and coupled social-ecological systems [103-106]. SESs are complex and multi-level systems studied at different scales and within diverse circumstances. Therefore, a number of conceptual frameworks are necessary for understanding different characteristics of SESs that reflect the variety of research disciplines involved in the study of SESs, including sustainability science, economics and ecological economics, geography, and environmental science, to name but a few, which all provide different perspectives regarding social-ecological interactions and outcomes. The SES frameworks bring the foundation for understanding the properties of a specific SES. Scholars have used the concept of socio-ecological systems to emphasize the integrated character of the relationships and interactions between social and natural systems. Theories for analyzing social-ecological systems have evolved to established and recognized paradigms for the science, the practice, and the policy of sustainability [107]. Prominent examples include the Social-Ecological Systems Framework [108-111], the Millennium Ecosystem Assessment Framework (Millennium Ecosystem Assessment 2003), and the framework suggested by the Intergovernmental Platform on Biodiversity and Ecosystem Services IPBES, aiming to extend our understanding of social-ecological systems beyond traditional Western science thinking [112].

\subsection{Data Science}

Data science is becoming a common buzzword, meaning collection, preparation, analysis, visualization, management, and preservation of data [113,114]. Moreover, some scholars chart the evolution of science through four paradigms: experimental science, theoretical science, computational science, and exploratory science [115]. The forth paradigm, also referred to as data science, is data-intensive and uses statistical exploration, machine learning, and data mining. However, other researchers, in particular those in the humanities and social sciences, given the diversity of their philosophical foundations, argue that data science, Big Data and new data analytics are unlikely to lead to new paradigms $[116,117]$. Data science presents two potential paths for research that have divergent epistemologies: (1) empiricism ("the data deluge makes the scientific method obsolete" [118]) and (2) data-driven science that completely modifies the existing scientific methods by combining features of abduction, induction and deduction. Given the weaknesses in the empiricist arguments, Kitchin [116] argues that the data-driven approach will remain dominant over time, presenting a strong challenge to the established knowledge-driven scientific method. The data, often unstructured, heterogeneous, and networked (emerged from networks with complex relations between its entities), has become ubiquitous in our society, leading the way towards the big data era [119]. Data analysis combines integration, interpretation, and knowledge discovery and is based on methods and tools from mathematics, statistics, information science, and computer science, but also from linguistics, sociology, 
and other disciplines. Data integration includes tools and technologies for data orchestration across diverse solutions such as, for example, Amazon Elastic MapReduce, Apache Hive, Apache Spark, MapReduce, Hadoop, and MongoDB, to mention only a few. Moreover, recent advances in AI and ML techniques have made computers active subjects in the decision making processes by enabling them to collect, analyze, and infer knowledge automatically. As the data generated by various electronic devices is typically used by other computers [113], automated decision-making processes have scaled so that it is becoming increasingly frequent for computers to make decisions. This, however, has triggered various concerns regarding accountability, fairness, ethics and privacy, which have recently been addressed in both computer science and social science [120].

\subsection{Digital Democracy}

The term digital democracy, defined simply as "the practice of democracy using digital tools and technologies" [121], summarizes various forms of citizens' engagements ranging from giving citizens only on-line access to governmental information to enabling citizens to participate in decision-making processes on-line. The last few years have witnessed a surge in digital democracy projects around the world: there are hundreds of digital tools and platforms being used to engage citizens in order to improve the quality, legitimacy and transparency of decision-making. Examples of digital democracy include LabHacker and eDemocracia (Brazil), Madame Mayor, I have an idea (France), Pirate Party (Iceland), Parlement \& Citoyens (France), vTaiwan (Taiwan), Better Neighbourhoods/Better Reykjavik (Iceland), Decide Madrid (Spain), to mention only a few. Other Internet-based democracy platforms include [122-124]. For a recent review of digital tools used by parliaments and municipal governments to engage citizens for improving the decision-making processes, we refer the readers to [121]. Linders suggested a transition from e-Government (citizen as customer) to We-Government (citizen as partner), "in which society places greater trust in - and empowers - the public to play a far more active role in the functioning of their government" [125]. The use of the Internet of Things, cloud computing, big data, machine learning and artificial intelligence are reshaping the values and practices of government, triggering "new government initiatives, named Internet Plus Government, which represents a new movement claiming to give full play to Web 2.0 in government innovation and social development in the last decade" [126].

\section{Design Principles for the ICT Framework}

The actors that participate in addressing SDGs include intergovernmental organizations, governments, enterprises, non-profit organizations, various civil society communities, and individuals, pursuing interests at different scales with respect to the time, space, and organization, as well as in diverse political, economic, socio-cultural, and environmental surroundings [127,128]. Governance and decision-making processes concerning SDGs are shaped not only by a large number of normative rules and regulations including laws, policies, agreements and technical standards, but also by administrative, commercial, professional, cultural, ethical and interpersonal practices [127,129]. Moreover, governance and decision-making processes are influenced by relationships of power, authority, and cooperation at multiple levels $[127,130]$. There are four different types of goods classified according to excludability and rivalrousness: common resources, public goods, private goods, and club goods. The governance of common resources is shaped by various actors at different spatial, temporal, and decision making scales. However, jurisdictional boundaries within the spatial, temporal, and decision making scales do not correspond with both the biophysical and spatial/temporal characteristics of common resources [127,131].

Addressing the sustainable development goals is guided by several principles. In general, sustainability could be considered a "thick" normative concept [132-134], i.e., it carries both normative and descriptive content. However, the critical political documents on this concept [135-137] have clearly contained the normative meaning and take sustainability as a guiding principle. SDGs are widely understood as something positive; each and every country should be committed and work 
vigorously towards achieving the objectives disclosed in these goals. Hence, we believe that the principles suggested here "ought to proceed" [138] in order to achieve the SDGs by their target date of 2030. We suggest four design principles for the ICT framework provided here, see Figure 3:

- Principle 1: SDGs performance should be shaped by three disciplines: governance science, sustainability science, and data science;

- Principle 2: SDGs implementation should be triggered by various actors at different spatial scales (e.g., farm, local, region, state, national, international), temporal scales (e.g., daily, monthly, annual) and decision making scales (e.g., individual, group, institution);

- Principle 3: SDGs governance should be emphasized by various governance theories (including adaptive governance, collaborative governance, network governance, and so on) triggering actions across many levels and involving actors from multiple sectors; and

- Principle 4: SDGs implementation should be influenced by the human behavior.

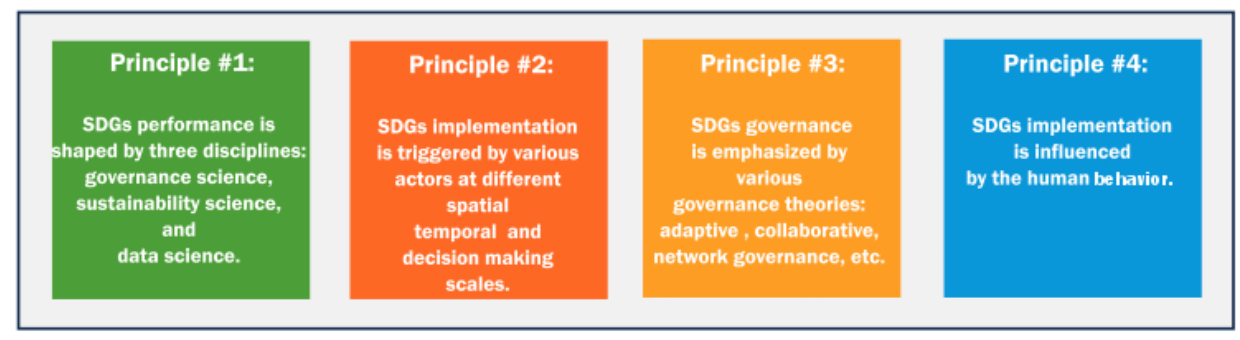

Figure 3. Four design principles for the ICT framework. The first principle shapes the basic building blocks of the framework: data module, sustainability module, and governance module. The second principle implements coordinated efforts of all active subjects: individuals, groups, governments, and intergovernmental institutions. The third principle empowers various governance theories to be used in the framework. The forth principle provides incentives and motivations for individuals to participate in the decision-making processes.

In the last five decades, scholars have built a solid field of sustainability science by working on ecological systems, socioeconomic systems, and linked socio-ecological systems. From the analysis of a variety of common resources, scholars have documented that community-based governance systems support the existence of common resources over the range from 100 years to 1000 years, surviving natural disasters as well as various social, political, and economical changes. How the vast body of knowledge of governance models already accumulated in the field of sustainability science can be transferred to SDGs? The principle 1 provides an answer to this question. Despite the enormous success of the social-ecological systems in addressing governance of common resources, this approach has not been adopted for SDGs and is lacking empowerment of citizens in addressing global challenges. Moreover, the approach has not fully adopted machine learning methods and tools for knowledge discovery and decision making tailored for SDGs. Machine learning methods have been recently used to track progress toward certain SDGs [139]. Several examples include methods for predicting poverty rates, housing conditions, food security or over-fishing estimations (SDG 1, 2, and 14) [140-142]. Pincet, Okabe, and Pawelczyk present a supervised learning technique to analyze text descriptions of Creditor Reporting Systems (CRSs) with 250,000 submissions per year to OECD [139]. The methodology assigns none, one, or multiple SDGs to each CRS project, depending on the score of the project description allowing studying the interlinkages between SDGs. As the methodology can be used to monitor SDGs financing, it allows policy analysts to estimate "how much aid targets each SDG and how the adoption of the 2030 Agenda has changed the behavior of donors" [139]. Nevertheless, the full potential of machine learning methods such as, for example, supervised learning, Bayesian approach, non-parametric modeling, reinforcement learning, graphical models, to mention only a few, to address SDGs has not yet been reached. Moreover, machine learning poses a host of ethical questions, including privacy and fairness [120] as well as paternalism, which will be briefly addressed 
at the end of this section. The main disadvantage of digital tools and platforms is the lack of sound scientific social-ecological systems framework for addressing global challenges.

The principle 3 ensures that the ICT framework is developed by considering several governance theories: Adaptive governance, Network governance, Collaborative governance, Accountable governance, Fair governance, and Trustworthy governance. The framework incorporates governance's structures that support a broad range of actors to deal with (1) interrelated dynamics of resources and ecosystems, (2) social and management systems, and (3) uncertainty and unpredictability. From an institutional perspective, management and governance can be thought of as nested rule structures. Ostrom [143] and Ostrom et al. [144] elaborate on the interconnected nature of rule-making structures and how this affects resource management. They suggest three levels of decision making processes: operational rules, collective choice rules and constitutional rules. Operational rules structure the day-to-day decisions about how to appropriate resources, provide information, monitor actions and enforce rules. Collective rules affect the policy and management decisions that determine the operational rules for managing a resource. Constitutional rules determine who is eligible to participate and the specific governance structure to be used in making collective choice rules.

When reflecting on governance for the 21st century, one of the central questions is the scale for implementing the SDGs. The principle 2 ensures that this question is addressed properly. Scholars have documented evidences that both institutions, the state and the market, are not successful in governing and managing common resources, rather communities of individuals could successfully govern common resources over long periods of time [143]. Scholars have already discussed the role and decreasing significance of nation states in the context of governance. Ohmae [145] argues that the nation state is an unfunctional structure for successfully organizing activities at social, economic and environmental levels. National governance systems are considered to be an ineffective structure when addressing challenges with respect to climate change, health care, and peoples' everyday problems [146]. Taleb [147] argues that cities are more optimally resistant to large changes and shocks than nation states as a sustainable political governance structure. Moreover, cities have recognized their transnational powers [146] and have already been organized in cooperative networks to address global challenges on the local level [148]. The suggestion to address environmental problems at the local (municipality/city) level was first posed in 1987 [149], triggering various activities regarding environmental concerns in urban areas [150-153]. Moreover, SDG 11 (Make cities and human settlements inclusive, safe, resilient and sustainable) focuses on urban sustainability $[154,155]$. Fuhr, Hickmann, and Kern [156] discuss the roles of cities in climate/environmental governance [157-159]. Fenton and Gustafsson [160] argue that SDGs can be successfully implemented only at the local level, stressing that local actions could provide both global and local attentiveness.

The principle 4 aims to address the growing interest in behavioral economics [161,162]. The assumption that individuals are rational [163] and "have complete information about all actions available to them, the likely strategies that others will adopt, and the probabilities of specific consequences that will result from their own choices" [164], has to be dismissed as inadequate. Several improvements will further enhance the governance model capabilities. One of them is concerned with taking into account other potential correlates of emotional response-gender, culture and personality typologies (for example, the classification of the Big Five personality traits). Moreover, Kosinski and his co-workers have shown [165] that psychological profiles of individuals can be accurately modeled, which, in turn, can be used to judge more accurately motivations and incentives of individuals to address global challenges. However, since these psychological profiles could be manipulated and used, for example, in political campaigns for delivering targeted and highly persuasive messages to people on social media, as in the case of Cambridge Analytica, utmost care should be taken regarding ethical questions when implementing SDGs. In the case of the Cambridge Analytica scandal, Facebook data was used in ways well beyond what users expected or intended. Since the enlightenment, traditional ethics consider various conditions for moral responsibility of an individual [166], three of which are agreed upon $[167,168]$ : causality, knowledge, and choice. ICTs have changed how these 
three conditions are perceived regarding individual decisions with specific and knowable results towards decisions that have been taken by others (including automated decisions made by algorithms) with unknown consequences for anyone [168]. The fact that a person does not know how the data is collected and can be used, is an obvious drawback regarding the person's knowledge and free will. The Internet of Everything further enhances the distance between one person's knowledge and will and the other person's source of information and power. Moreover, big data leads to a great disproportion between various stakeholders, benefiting mostly those who can generate knowledge from data [168]. ICTs have triggered the development of digital ethics, also known as computer, information or data ethics [169]. Richards and King suggest [170] four high-level principles for setting up legal and ethical big data norms. Floridi [171] discusses digital governance, digital ethics and digital regulation, and their relationships. In particular, Floridi [171] defines digital ethics as "the branch of ethics that studies and evaluates moral problems relating to data and information (including generation, recording, curation, processing, dissemination, sharing and use), algorithms (including AI, artificial agents, machine learning and robots) and corresponding practices and infrastructures (including responsible innovation, programming, hacking, professional codes and standards), in order to formulate and support morally good solutions (e.g., good conduct or good values)".

Using social networks and ICTs for addressing SDGs could raise another concern regarding autonomy [172] and paternalism [173]. ICT has triggered research activities about the concept of "weak" or "soft" paternalism [174]. Soft paternalism uses methods and tools from behavioral sciences to develop policies and systems of choice aiming to nudge users toward improved decisions without restricting their options. Nudging can be most useful in contexts where users are confronted with uncertain, subjective trade-offs and scenarios that involve weighing possibly conflicting considerations [175]. Sustainable development is per se a contradicting concept: development involves intervention in our environment, and hence, diminishes natural resources, while sustainability means that natural resources should be preserved for an indefinite period. Therefore, SDGs are designed to "mitigate this paradox and to provide a rapprochement between ecological (sustainability) and economic (development) interests to cope with the ecological crisis without affecting existing economic growth [176,177]" [71]. As nudging for SDGs has not been addressed so far, one should ask first whether it is appropriate to nudge citizens at all, and if yes, toward what SDGs and how and who should develop and deploy those nudges [175].

\section{The ICT Framework Description}

This section describes our approach to an ICT framework for sustainable development goals. We follow Ostrom in using the terms "framework", "theory", and "model" [109,110]. Frameworks are meta-theoretical concepts/devices for providing a general language for describing relationships at multiple levels and scales. Theories, which are analytical tools for understanding, explaining, and making predictions, can be generated (translated) from frameworks by making assumptions about variables/attributes and their relationships for a particular framework of a socio-ecological system. Models are very specific working examples of a theory. Therefore, the ICT framework aims to provide the basic lexicon of concepts and terms [110] to be used in building ICT platforms for addressing SDGs.

The ICT framework consists of three modules, Figure 4: data module, sustainability module, and governance module. It envisions governance systems and procedures that address SDGs on the local level by assessing/modeling various social-ecological systems, which are connected in a network of local platforms, ensuring global challenges to be addressed holistically. The methods from network governance together with mixed qualitative and social network analysis can be used (1) to ascertain the link between network governance properties, leadership positions and decision-making outcomes, (2) to assess network management strategies and their relation to outcomes, and (3) to analyze relations across multiple levels of networks in order to improve understanding of processes and outcomes. Moreover, the platform links social networks, behavioral sciences, data science, governance science, 
and digital technologies to effectively address SDGs by creating intelligent governance models and decision-making tools for citizens and governing bodies.

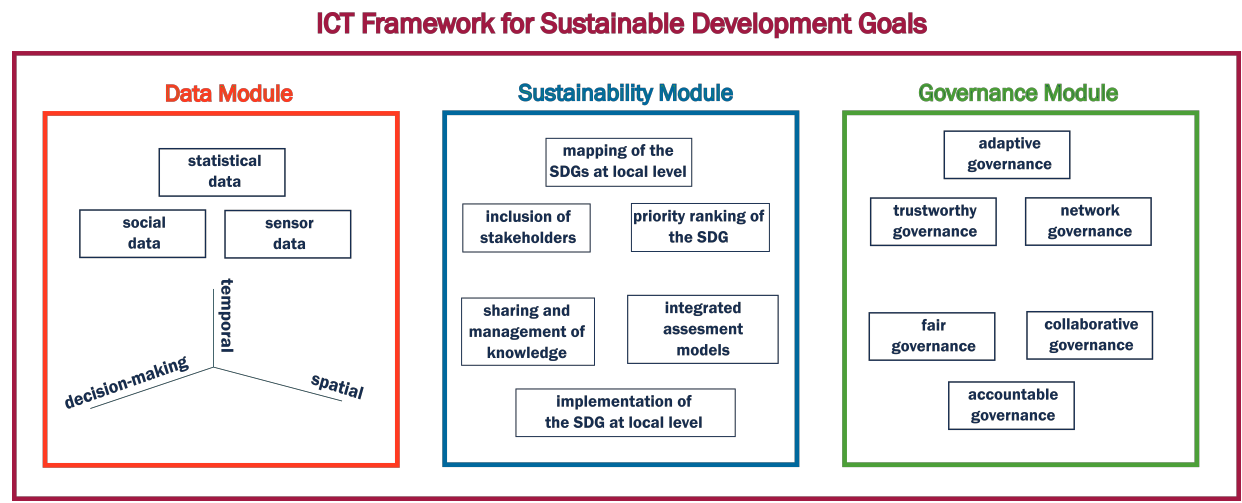

Figure 4. Three building blocks of the ICT framework: data module, sustainability module, and governance module. Data module aims to collect, prepare, analyze (compute and transform), visualize, manage and preserve data from three sources: statistical, sensor, and social data at three levels of granularity: spatial, temporal, and decision making. Sustainability module aims to map SDGs at local level, to ensure inclusion of stakeholders, to provide priority ranking of SDGs, to implement SDGs at local level, and to share and manage knowledge. Governance module aims to provide adaptive, network, collaborative, fair, and trustworthy governance.

The network of local platforms ensures that the concepts of tele-coupling and polycentric governance are implemented. Tele-coupling, a novel interdisciplinary umbrella concept, refers to those interactions between coupled human/natural systems that take place over distances [105]. Moreover, interactions within a system are called intra-coupling interactions, while peri-coupling refers to environmental and socio/economic interactions between adjacent systems [178]. Ostrom [164] has developed the concept of "polycentric governance" aiming to understand complex interconnected governance systems by considering various decision-making actors that operate with some level of self-governance, but are connected through processes of collaboration, coordination, and/or conflict $[179,180]$.

\subsection{Data Module}

This module aims:

- To collect, prepare, analyze (compute and transform), visualize, manage and preserve data from three sources: statistical, sensor, and social data at three levels of granularity: spatial, temporal, and decision making;

- To integrate linked open data, sensor network data, and data from social networks and blogs, resulting in a context-aware realization of the SDGs;

- To collect the Agenda 2030 indicators;

- To collect data relevant to SDGs (including social data) to be used for computing other indicators as well as proxy indicators and for analyzing citizens' behavior regarding SDGs;

- To provide data for the Sustainability module relevant for computing integrated (composite) indicators and for modeling social-ecological systems; and

- $\quad$ To provide data for the Governance module.

Data will be collected from different sources arranged in three groups [181]: (1) Statistical data (data from national and EU statistical agencies, data from other governmental and non-governmental agencies, various open-data available in periodical reports or in continuous mode), (2) Sensor data (data from sensors owned by governmental agencies as well as from sensors owned by various vendors, and data from citizens' sensors such as wearable sensors, mobile smart-phones, in-vehicle sensors, etc.), 
and (3) Social data (data from social networks, blogs, and data from newspapers or news aggregating portals). Levels of granularity include spatial (e.g., local, region, state, national, international), temporal (e.g., daily, monthly, annual), and decision making (e.g., individual, group, institution). This module analyses data and provides input data for the other two modules. By adopting machine learning algorithms, it also incorporates several advanced behavior science concepts in order to improve the motivation for participating on the platform. Social data will be used for providing context-sensitive models of decision-making processes for understanding characteristics of citizens' environmental behavior, which could be reflected in addressing SDGs [182]. Data also generates various indicators (including also proxy indicators): social and ecological performance measures. A proxy indicator provides an indirect measure that approximates or is related to a quantity in the absence of a direct measure. Therefore, proxy indicators are derived from real-time processes and could be implemented to provide social and ecological performance measures in greater detail [181].

\subsection{Sustainability Module}

This module aims:

- To implement sustainable development goals/targets at the level of municipality/city and to provide upscaling of local SGGs initiatives and actions;

- To mobilize citizens to promote practical solutions for sustainable development;

- To provide a platform for ensuring stakeholders' engagement, partnerships, communication and outreach, and for offering knowledge management;

- To illustrate how and in what ways a municipality/city can integrate the goals/targets in its strategies, policies and practices;

- To ensure ranking of locally transformed goals/targets introducing primary, secondary, and so on goals/targets;

- To provide guidance on scientific assessments of the locally implemented goals/targets, to distinguish various paths for mitigating potential trade-offs, and to maximize synergies between the social, economic and environmental objectives;

- To provide ranking of social-ecological systems within the municipality/city;

- To provide scientific evidence and theoretical foundation for computing integrated (composited) indicators; and

- To ensure that sustainable development should be considered in a more general framework as a normative value system by addressing "three moral imperatives: satisfying human needs, ensuring social equity, and respecting environmental limits" [57].

Integrated assessment modeling is a tool used by various stakeholders for prediction and forecasting, for enhancing the productiveness and fruitfulness of decision-making and management, and for improving social learning as well as system understanding. Models holistically integrate biophysical, social and economic processes, their interactions and responses to changes. Kelly et al. [183] review five common approaches for integrating knowledge by considering various modeling approaches ranging from differential equations to statistical modeling. Social learning refers "to the capacity of a social network to communicate, learn from past behavior, and perform collective action, e.g., dealing with complex technical tasks and at the same time the social relational activities" [183], see also [184,185].

Social-ecological systems framework (SESF), developed by Ostrom and her colleagues, has been evolved incrementally over decades by considering a large number of empirical cases [111]. Ostrom and her colleagues collected concepts and variables across cases. Different logical categories are termed "tiers" organized hierarchically so that lower-level tiers account for subdivisions within elements of the next higher tier. The first-tier variables include: Social, economic, and political settings (S), Resource systems (RS), Governance systems (GS), Resource units (RU), Actors (A), Interactions (I), Outcomes (O), and Related ecosystems (ECO). Further development and application of the SES framework has 
discussed the formal relationships between concepts and variables of the framework [111]. McGinnis and Ostrom [110] suggested a three-step process for an application of the SES framework to particular cases. In the first step, a level of analysis has to be selected by considering interactions and outcomes related to a particular resource system and related resource units, actors involved, and governance systems that impact the actors' behavior. In the second step, variables to be measured and indicators to be implemented are selected. Finally, the last step enhances the effectiveness of communicating and conveying outcomes and results across research communities.

Variables/attributes, identified for studying SESs, are organized in a nested multi-layer or multi-tier structure. Each of the eight broad subsystems can be analyzed into their component and further analyzed into their multiple conceptual tiers (layers). SESF helps to understand different types of actions, activities and processes undertaken by actors and the interaction of these actions with other variables in determining social-ecological outcomes and dynamics of SESF. The outcomes in this framework include social performance measures (efficiency, equity, accountability, sustainability) and ecological performance measures (over-harvesting, resilience, biodiversity, sustainability). Therefore, the sustainability module transforms outcomes of the specific socio-ecological system to the (dis-aggregated) indicators of the Agenda 2030.

The fifth subsystem Interaction refers to social, economical, and environmental processes through which interactions lead to outcomes. Depending on the considered system, different models could be employed [183]: (1) System dynamics assume formalism based on ordinary differential (or difference) equations, representing causal relationships, feedback loops, delays, and decision rules of variables that generate system behavior; (2) Graphical models assume that variables are represented by nodes connected by links (random Markov fields) or arrows (Bayesian networks) representing dependences (or casual dependences in the case of Bayesian networks); (3) Agent-based models focus on interactions between autonomous entities (agents), representing individuals or groups, as well as the links between agents and their behavioral patterns; (4) Knowledge-based models are (computer) programs that use knowledge base (a method/technology for storing structured and unstructured information) for automated reasoning and inferring conclusions (inference engine), adopting rule-based methods ("if-then-else" rules) or logic-based methods, formalized according to a logic system; and (5) Hybrid models involve combining models for producing an integrated outcome, including the previous four modeling approaches.

Although SESF framework has proven capabilities of addressing common resources as documented in many works of Ostrom and her colleagues, nevertheless, "current analytical and quantitative modeling capabilities fall short of being able to capture all 17 SDGs and their targets" [63]. Moreover, Shared Socio-economic Pathways (SSPs), established by the climate change research community for enhancing and facilitating the integrated analysis of future climate impacts, do not aim to address all SDGs. For example, even the most advanced pathways such as SSP1/SSP1-2.6, do not meet all SDGs and do not provide information on some of them [63]. Integrated assessment models used for the development of the SSP scenarios include:

- IMAGE, the Integrated Model to Assess the Global Environment [186];

- MESSAGE-GLOBIOM, the Model for Energy Supply Strategy Alternatives and their GeneralEnvironmental Impact combined with the Global Biosphere Management Model [187];

- $\quad$ AIM, the Asia-pacific Integrated Model [188];

- GCAM4, the Global Change Assessment Model [189];

- REMIND-MAgPIE, the Regionalized Model of Investments and Development combined with the Model of Agricultural Production and its Impact on the Environment [190]; and

- WITCH-GLOBIOM, the World Induced Technical Change Hybrid model combined with GLOBIOM [191]. 


\subsection{Governance Module}

This module aims:

- To implement various modern theories of governance, in particular adaptive, network governance, collaborative, and accountable governance;

- To introduce and implement novel governance theories such as fair and trustworthy governance;

- To offer new forms of citizen engagement and more flexible and integrated modes of governing by adopting the theories of governance;

- To allow two-way communications between government and people and effective citizen engagement by enabling citizens (a) to raise awareness of particular issues; (b) to provide ideas for new, improved or future solutions; (c) to generate, develop and amend specific proposals individually, collectively or collaboratively; and/or with state officials; (d) to monitor and assess public actions and services; and (e) to make decisions e.g., through referendums, voting on specific proposals or participatory budgeting;

- To integrate knowledge about individual incentives and barriers to collection action, collaborative social learning and conflict resolution processes, and institutional arrangements for cross-boundary collaboration; and

- To provide means for the framework to have true impacts of SDGs by motivating citizens to participate in addressing SDGs and by enabling those in positions of power to endorse the framework.

Global governance reflects the processes of governing global relationships between individuals and institutions aiming to manage their common affairs [192]. Improving global governance for sustainable development can only be achieved synergistically by considering "regional, national and local circumstances, cutting across many policies, programmes, institutions and sectors" [127] and by ensuring "more inclusive participatory processes at local community scales" [127]. The ICT platform to be developed by using the framework described here, will ensure "transnational sharing, discussion and synthesis of different approaches" to sustainable development governance enabling "all participating actors to benefit from the global collective experience, and overcome key barriers to change including knowledge gaps, capacity challenges, or the absence of supportive political commitment" [127]. Recently some scholars argued that SDGs present a novel approach to global governance, 'Governance through goals', which is marked by four characteristics [193,194]: (1) goal-setting global governance is uncoupled to the international legal system as SDGs are not legally binding; (2) governance through goals provides weak institutional arrangements at the intergovernmental level; (3) goal-setting global governance ensures global inclusion and comprehensiveness [195-197] by considering input from at least 70 governments as well as numerous representatives of civil society; and (4) global governance through goals provides flexibility to national/regional options, outcomes, and desires.

Reviewing various governance theories or even providing definitions of the concepts of adaptive governance, network governance, collaborative governance, and accountable governance, is beyond the scope of the paper. Previous literature on adaptive governance includes, for example, refs. [198-200]. Dietz et al. [201] use the term "adaptive governance" to expand the focus from adaptive management to address the explicit institutional context that supports adaptive management. Network governance represents a form of "social organization in which interpersonal relational aspects such as trust, reciprocity and the pursuit of mutual benefit interact to forge jointly agreed and achieved outcomes" [202]. As networks are an important form of multi-organizational governance [203], network governance has been studied in [204-207]. Collaborative governance [208] includes any "method of collective decision-making where public agencies and non-state stakeholders engage each other in a consensus-oriented deliberative process" [209]. Koppell [210] distinguishes no less than five different dimensions of accountability: transparency, liability, controllability, responsibility, and responsiveness. Accountable governance has been studied in [211-213]. Proposals for implementing 
various governance theories are often made in pure normative terms. A brief description on concrete approaches for implementing them includes:

- Adaptive governance can be implemented by addressing institutional, cross-scale challenges and the structures and incentives, by considering Iterative decision-making mechanisms, by providing feedback between monitoring and decisions learning, by explicit characterization of system uncertainty through multi-model inference, and by implementing legal and institutional oversight, or built-in mechanisms for adaptation;

- Network governance can be implemented as a network of local ICT platforms, offering an approach to organize and mobilize stakeholders for improving social, economic and environmental outcomes;

- Collaborative governance can be implemented as a collaborative unit that consists of individuals with diverse backgrounds by providing methods and tools for the members of the unit to develop and adopt a collective consciousness in addition to their own identities, preferences and motivations; and

- Accountable governance can implement two aspects of accountability: (1) accountability of officials, governmental agencies, or organizations involved in the decision making process, and (2) accountability of the ICT framework itself, by involving systems and coordinated actions for control, sanctions, and for creating conditions for improved accountability and governance.

In addition, this module introduces two new forms of governance. Fair governance here refers (1) to fairness of the whole governance regime supported by the platform and (2) to fairness of the automated decision-making algorithms. Trustworthy governance refers to (1) consideration of the full range of stakeholders within the framework; (2) ability to audit data use and data management within the framework; (3) transparency of operations, governance, and decision making supported by the framework; and (4) consideration of the long term financing and management of the implemented framework. To address fair governance, the ICT framework can implement techniques for avoiding outcomes of decision-making processes that could be considered discriminatory [120]. Trustworthy governance can be implemented as distributed trust by providing mechanisms for increased levels of trust among participants (individuals), for example, by using blockchain technology [214]. The possibility to ensure proportional-fairness of the governance process can be addressed by considering a custom-designed blockchain mechanism that maintains a distributed database trusted by all peers. One can adopt Hyperledger Fabric [215] for novel blockchain global governance model. Hyperledger Fabric has a ledger, uses smart contracts, and is a system by which participants, enrolled through a membership service provider, manage their transactions.

\section{Conclusions}

We have suggested an ICT framework for addressing sustainable development goals. Following the four principles, this framework aims to provide a pathway for designing and building an ICT platform: (1) SDGs performance should be shaped by three disciplines: governance science, sustainability science, and data science, (2) SDGs implementation should be triggered by various actors at different spatial scales, temporal, and decision making scales, (3) SDGs governance should be emphasized by various governance theories triggering actions across many levels and involving actors from multiple sectors, and (4) SDGs implementation should be influenced by the human behavior. The proposed framework is actually the first attempt to conceptualize the SDGs (as an ICT-supported phenomenon) in the light of existing discussions in governance science, sustainability science, and data science. In other words, the benefits of using this framework refer to the following novel features:

(a) holistic approach that integrates three disciplines-governance science, sustainability science, and data science-bonded with the concept of digital democracy;

(b) increased-awareness approach that leads to governance of SDGs on both local and global levels; 
(c) data-intensive approach in which SDGs are implemented by using state-of-the-art machine learning methods at different spatial, temporal, and decision making scales;

(d) governance-enhanced approach in which SDGs are implemented by considering various governance theories: adaptive governance, network governance, collaborative governance, accountable governance, fair governance, and trustworthy governance;

(e) two-way approach that ensures communications between government and people and effective citizen engagement in addressing SDGs; and

(f) responsible approach that provides true impacts on SDGs by motivating citizens to participate in addressing SDGs and by enabling those in positions of power to endorse the framework.

Nevertheless, there are a few situations where this framework exhibits certain limits. First, the process of developing an ICT framework is iterative and could last for some time. For example, the social-ecological system (SES) framework was initially proposed in 2007, however, members of the SES club reported and discussed "a few remaining ambiguities in its formulation" in 2014 [110]. Second, the ICT framework we suggest here is a conceptual one and could face several challenges when implemented on a platform, especially those related to privacy, accountability, fairness, and paternalism. Any further work on the topic should take into account these limits, and should also address the soft paternalism and nudging for SDGs, including the issues related to the outcomes of nudging and the actors in charge of their implementation.

As mentioned above, this framework could provide a supporting knowledge for building an ICT platform. We provide here only a brief guideline for the practical development and deployment of such a platform. For example, it could be designed and implemented as the ISO-Standardized Smart City Platform, developed and deployed for the city of Skopje, Macedonia [181]. The platform's application layer architecture could consist of several modules including a data gathering module, core intelligence reasoning module, security module for authentication, and user interface (front-end) module accessed via web and mobile applications, web services, and secure services for cloud/edge/fog and IoT integration [181]. The front-end module could have several dashboards: personal dashboard, real-time municipality dashboard, municipality dashboard, global dashboard. The "social networks integration" API could connect citizens to social network accounts and ranks users based on their involvement in improving SDGs. The API can share scores continuously (daily or weekly) and provide suggestions to enhance SDGs, thus motivating and empowering citizens to actively participate using the platform [181]. When it comes to development of a prototype of the ICT platform one could follow open standards and use open source technologies on an enterprise software framework, available in the Java Spring platform (Spring MVC). We refer the reader to [181] for a full account on how to develop and deploy the ICT platform for SDGs. Finally, for an ICT platform to be successful and to have a real impact on sustainable development goals, it has:

- to be tailored to SDGs priorities based on a local community values and needs;

- to be guided by the motivation for participation: either a citizen's contribution is able to influence and shape decisions, or it is related to some intrinsic motivation, or because addressed issues are substantive;

- to allow coordinated efforts of individuals, groups, governments, and intergovernmental institutions, by extending the concepts of orchestration and policy diffusion already suggested in global climate governance [216];

- to provide a mixture of on-line and off-line for bridging the digital divide and increasing the legitimacy of decision-making by broadening the pool of participants.

It is noteworthy to mention, however, that any further debate on smart cities should be refocused and must also pay greater attention to policy making and strategy reflections [217]. For these reasons, the future policy-oriented smart city research should take into account some open issues that exist at different levels [218] micro level (e.g., "unified approach to data repository management"; the use of block chain and e-payment technologies; deployment of artificial intelligence to support the most 
important, universal recommender systems adept to process big data in real time and for any kind of reasons, etc.), middle level (e.g., design of the "adaptive, context-aware anticipatory computing crawlers and services that will add additional insight to data profiles" [218]), and macro level where data management strategies are contended with a certain degree of risk and uncertainty.

In summary, although SDGs "are mostly vague, largely immeasurable, somewhat attainable, and definitely relevant" [219], each individual should endeavor to help implement these global goals by "leading the way in figuring out how to make the impossible possible" [219]. Therefore, as human pressure on the Earth System is still increasing [220], "rather than sitting like Vladimir and Estragon, who wait endlessly and in vain for someone named Godot to arrive" [57], a person should react for her/his wellbeing as well as for the advancement of our society, not wait for others to act. This article is a small contribution to the common cause of undertaking ambitious efforts to achieve the SDGs.

Author Contributions: The authors contributed equally to this work.

Funding: This research was funded by ONR/ONR Global grant number N62909-16-1-2222.

Conflicts of Interest: The authors declare no conflict of interest. The funders had no role in the design of the study; in the collection, analyses, or interpretation of data; in the writing of the manuscript, or in the decision to publish the results.

\section{References}

1. Transforming Our World: The 2030 Agenda for Sustainable Development. Available online: https:// sustainabledevelopment.un.org/post2015/transformingourworld (accessed on 10 January 2019).

2. About the Sustainable Development Goals. Available online: https://www.un.org/ sustainabledevelopment/sustainable-development-goals / (accessed on 10 January 2019).

3. ICT \& SDGs-How Information and Communications Technology Can Accelerate Action on the Sustainable Development Goals; Final Report; The Earth Institute Columbia University: New York, NY, USA, 2016. Available online: https:/ / www.ericsson.com/assets/local/about-ericsson/sustainability-and-corporateresponsibility/documents/ict-sdg.pdf (accessed on 10 January 2019).

4. Broadband Commission. Means of Transformation, ITU/UNESCO; Broadband Commission: Kigali, Rwanda, 2014. Available online: https:/ / www.broadbandcommission.org/documents/reports/bb-annualreport2014. pdf (accessed on 10 January 2019).

5. The Global Information Technology Report 2010-2011. Available online: http://reports.weforum.org/ global-information (accessed on 25 December 2018).

6. WSIS—SDG Matrix. Available online: https://www.itu.int/net4/wsis/sdg/ (accessed on 12 January 2019).

7. Korotayev, A.; Tsirel, S. A Spectral Analysis of World GDP Dynamics: Kondratieff Waves, Kuznets Swings, Juglar and Kitchin Cycles in Global Economic Development, and the 2008-2009 Economic Crisis. Struct. Dyn. 2010, 4. Available online: https:/ / escholarship.org/uc/item/9jv108xp (accessed on 12 January 2019).

8. The Sixth Kondratieff_Long Waves of Prosperity; Allianz Global Investors: Frankfurt, Germany. Available online: https:/ / www.allianz.com/content/dam/onemarketing/azcom/Allianz_com/migration/media/ press/document/other/kondratieff_en.pdf (accessed on 20 November 2018).

9. Silva, G.; Serioa, L.C.D. The sixth wave of innovation: Are we ready? Revista de Administracao e Inovacao 2016, 13, 128-134. [CrossRef]

10. Atrostic, B.K.; Boegh-Nielsen, P.; Motohashi, K.; Nguyen, S. IT, productivity and growth in enterprises: Evidence from new international micro data. The Economic Impact of ICT-Measurement, Evidence and Implications. In Proceedings of the OECD Workshop on ICT and Business Performance, Paris, France, 9 December 2002.

11. Arvanitis, S.; Loukis, E.N. Information and communication technologies, human capital, workplace organization and labour productivity: A comparative study based on firm-level data for Greece and Switzerland. Inf. Econ. Policy 2009, 21, 43-61. [CrossRef]

12. Cardona, M.; Kretschmer, T.; Strobel, T. ICT and productivity: Conclusions from the empirical literature. Inf. Econ. Policy 2013, 25, 109-125. [CrossRef]

13. Hristoski, I.; Kostoska, O. System dynamics approach for the economic impacts of ICTs: Evidence from Macedonia. Inf. Dev. 2018, 34, 364-381. [CrossRef] 
14. Bresnahan, T.F.; Trajtenberg, M. General purpose technologies: 'engines of growth'? J. Econom. 1995, 65, 83-108. [CrossRef]

15. Biagi, F. ICT and Productivity: A Review of the Literature. JCR Technical Reports. Institute for Prospective Technological Studies; Digital Economy Working Paper; Publications Office of the European Union: Luxembourg, 2013.

16. Gossart, C. Rebound Effects and ICT: A Review of the Literature. In ICT Innovations for Sustainability, Advances in Intelligent Systems and Computing; Springer International Publishing: Cham, Switzerland, 2015; pp. 435-448. ISBN 978-3-319-09227-0.

17. Hilty, L.M.; Köhler, A.; von Schéele, F.; Zah, R.; Ruddy, T. Rebound Effects of Progress in Information Technology. Poiesis Prax. 2006, 4, 19-38. [CrossRef]

18. Townsend, J.H.; Coroama, V.C. Digital Acceleration of Sustainability Transition: The Paradox of Push Impacts. Sustainability 2018, 10, 2816. [CrossRef]

19. Hilty, L.M. Information Technology and Sustainability: Essays on the Relationships between Information Technology and Sustainable Development; Books on Demand: Norderstedt, Germany, 2008. Available online: https: / / www.bod.de/ (accessed on 10 January 2019).

20. Steinberger, J.K.; van Niel, J.; Bourg, D. Profiting from negawatts: Reducing absolute consumption and emissions through a performance-based energy economy. Energy Policy 2009, 37, 361-370. [CrossRef]

21. Murray, C.K. What if consumers decided to all 'go green'? Environmental rebound effects from consumption decisions. Energy Policy 2013, 54, 240-256. [CrossRef]

22. Throne-Holst, H.; Stø, E.; Strandbakken, P. The role of consumption and consumers in zero emission strategies. J. Clean. Prod. 2007, 15, 1328-1336 [CrossRef]

23. Passey, R.; MacGill, I. Energy sales targets: An alternative to White Certificate schemes. Energy Policy 2009, 37, 2310-2317 [CrossRef]

24. Shay, S.B. MIT Technology Review; 2008; Volume 111. Available online: https://www.technologyreview.com/ s/410347/bigfoot/ (accessed on 10 December 2018).

25. Sharafat, A.R.; William, H.; Lehr, W.H. ICT Engines for Sustainable Development. In ICT-Centric Economic Growth, Innovation and Job Creation; Sharafat, A.R., Lehr, W.H., Eds.; 2017. Available online: https:/ /www.itu. int/dms_pub/itu-d/opb/gen/D-GEN-ICT_SDGS.01-2017-PDF-E.pdf (accessed on 14 February 2019).

26. Andrae, A.; Edler, T. On global electricity usage of communication technology: Trends to 2030. Challenges 2015, 6, 117-157. [CrossRef]

27. Pouri, M.J.; Hilty, L.M. Conceptualizing the Digital Sharing Economy in the Context of Sustainability. Sustainability 2018, 10, 4453. [CrossRef]

28. Hilty, L.M.; Aebischer, B. ICT for sustainability: An emerging research field. In ICT Innovations for Sustainability; Advances in Intelligent Systems and Computing; Hilty, L.M., Aebischer, B., Eds.; Springer: Cham, Switzerland, 2015; Volume 310, pp. 3-36.

29. Joseph, G. Ambiguous but tethered: An accounting basis for sustainability reporting. Crit. Perspect. Account. 2012, 23, 93-106. [CrossRef]

30. Dixon J.A.; Fallon L.A. The concept of sustainability: Origins, extensions, and usefulness for policy. Soc. Nat. Resour. 1989, 2, 73-84. [CrossRef]

31. Giovannoni, E.; Fabietti, G. What Is Sustainability? A Review of the Concept and Its Applications; Integrated Reporting; Busco, C., Frigo, M.L., Riccaboni, A., Quattrone, P., Eds.; Springer International Publishing: Cham, Switzerland, 2014. [CrossRef].

32. Gray, R. Is accounting for sustainability actually accounting for sustainability. . and how would we know? An exploration of narratives of organisations and the planet. Account. Organ. Soc. 2010, 35, 47-62. [CrossRef]

33. Drexhage, J.; Murphy, D. Sustainable Development: From Brundtland to Rio 2012, Background Paper for the High Level Panel on Global Sustainability; United Nations: New York, NY, USA, 2010. Available online: http:/ / www.surdurulebilirkalkinma.gov.tr/wp-content/uploads/2016/06/Background_ on_Sustainable_Development.pdf (accessed on 10 January 2019).

34. Sachs I. The strategies of ecodevelopment. Ceres 1984, 17, 17-21.

35. Tivy, J.; O'Hare, G. Human Impact on the Ecosystem; Oliver and Boyd: Edinburgh, UK, 1982.

36. Dempsey, N.; Bramley, G.; Power, S.; Brown, C. The social dimension of sustainable development: Defining urban social sustainability. Sustain. Dev. 2011, 19, 289-300. [CrossRef] 
37. Biermann, F. Earth System Governance: World Politics in the Anthropocene; MIT Press: Cambridge, MA, USA, 2014.

38. Mitchell, R.B. International environmental agreements: A survey of their features, formation, and effects. Annu. Rev. Environ. Resour. 2003, 28, 429-461. [CrossRef]

39. Young, O.R. Effectiveness of international environmental regimes: Existing knowledge, cutting-edge themes, and research strategies. Proc. Natl. Acad. Sci. USA 2011, 108, 19853-19860. [CrossRef]

40. Ebbesson, J.; Hey, E. Introduction: Where in law is social-ecological resilience? Ecol. Soc. 2003, 18, doi:10.5751/ES-05750-180325 [CrossRef]

41. Freestone, D.; Hey E. The Precautionary Principle and International Law: The Challenge of Implementation; Kluwer Law International: The Hague, The Netherlands; London, UK; Boston, MA, USA, 1996.

42. Kingsbury, B.; Casini, L. Global administrative law dimensions of international organizations law. Int. Organ. Law Rev. 2009, 6, 319-358. [CrossRef]

43. Heidbreder, E.G. Multilevel policy enforcement: Innovations in how to administer liberalized global markets. Public Adm. 2015, 93, 940-955. [CrossRef]

44. Frank, A.B.; Collins, M.G.; Levin, S.A.; Lo, A.W.; Ramo, J.; Dieckmann, U.; Kremenyuk, V.; Kryazhimskiy, A.; Linnerooth-Bayer, J.; Ramalingam, B.; et al. Dealing with femtorisks in international relations. Proc. Natl. Acad. Sci. USA 2014, 111, 17356-17362. [CrossRef] [PubMed]

45. Turnhout, E.; Hisschemöller, M.; Eijsackers, H. Ecological indicators: Between the two fires of science and policy. Ecol. Indic. 2007, 7, 215-228. [CrossRef]

46. Mair, S.; Druckman, A.; Jackson, T. Global Inequities and Emissions in Western European Textile and Clothing Consumption. J. Clean. Prod. 2016, 132, 57-69. [CrossRef]

47. Mair, S.; Jones, A.; Ward, J.; Christie, I.; Druckman, A.; Lyon F. A Critical Review of the Role of Indicators in Implementing the Sustainable Development Goals. In Handbook of Sustainability Science and Research; World Sustainability Series; Leal Filho, W., Ed.; Springer: Cham, Switzerland, 2018.

48. Frey, D.; MacNaughton, G. A Human Rights Lens on Full Employment and Decent Work in the 2030 Sustainable Development Agenda. J. Workp. Rights 2016, 6, 1-13. [CrossRef]

49. Burchell, B.; Sehnbruch, K.; Piasna, A.; Agloni, N. The quality of employment and decent work: Definitions, methodologies, and ongoing debates. Camb. J. Econ. 2014, 38, 459-477. [CrossRef]

50. Hák, T.; Janoušková, S.; Moldan, B. Sustainable development goals: A need for relevant indicators. Ecol. Indic. 2016, 60, 565-573. [CrossRef]

51. GBD 2016 SDG Collaborators. Measuring progress and projecting attainment on the basis of past trends of the health- related Sustainable Development Goals in 188 countries: An analysis from the Global Burden of Disease Study 2016. Lancet 2017, 390, 1423-1459.

52. Sterman, J. Business Dynamics: Systems Thinking and Modeling for a Complex World; Irwin/McGraw-Hill: Boston, MA, USA, 2000.

53. Hilty, L.; Lohmann, W. An Annotated Bibliography of Conceptual Frameworks in ICT for Sustainability. In Proceedings of the ICT4S-First International Conference on Information and Communication Technologies for Sustainability, Zürich, Switzerland, 12-14 February 2013; pp. 288-300.

54. Tjoa, A.M.; Tjoa, S. The Role of ICT to Achieve the UN Sustainable Development Goals (SDG); Mata, F.J., Pont, A., Eds.; Springer International Publishing: Cham, Switzerland, 2016; pp. 3-13.

55. Costanza, R.; Daly, L.; Fioramonti, L.; Giovannini, E.; Kubiszewski, I.; Mortensen, L.F.; Pickett, K.E.; Ragnarsdottir, K.V.; De Vogli, R.; Wilkinson, R. Modeling and measuring sustainable wellbeing in connection with the un sustainable development goals. Ecol. Econ. 2016, 130, 350-355. [CrossRef]

56. Janowski, T. Implementing sustainable development goals with digital government-Aspiration-capacity gap. Gov. Inf. Q. 2016, 33, 603-613. [CrossRef]

57. Holden, E.; Linnerud, K.; Banister, D. The Imperatives of Sustainable Development. Sustain. Dev. 2017, 25, 213-226. [CrossRef]

58. Allen, G.; Metternicht, G.; Wiedmann, T. Initial progress in implementing the Sustainable Development Goals (SDGs): A review of evidence from countries. Sustain. Sci. 2018, 13, 1453-1467. [CrossRef]

59. Wu, J.; Guo, S.; Huang, H.; Liu, W.; Xiang, Y. Information and Communications Technologies for Sustainable Development Goals: State-of-the-Art, Needs and Perspectives. IEEE Commun. Surv. Tutor. 2018, 20, 2389-2406. [CrossRef] 
60. Linkov, I.; Trump, B.D.; Poinsatte-Jones, K.; Florin, M.-V. Governance Strategies for a Sustainable Digital World. Sustainability 2018, 10, 440. [CrossRef]

61. Campagnolo, L.; Eboli, F.; Farnia, L.; Carraro, C. Supporting the UN SDGs transition: Methodology for sustainability assessment and current worldwide ranking. Economics 2018, 12, 1-31. [CrossRef]

62. Nerini, F.F.; Tomei, J.; To, L.S.; Bisaga, I.; Parikh, P.; Black, M.; Borrion, A.; Spataru, C.; Broto, V.C.; Anandarajah, G.; et al. Mapping synergies and trade-offs between energy and the Sustainable Development Goals. Nat. Energy 2018, 3, 10-15. [CrossRef]

63. Zimm, C.; Sperling, F.; Busch, S. Identifying Sustainability and Knowledge Gaps in Socio-Economic Pathways Vis-á-Vis the Sustainable Development Goals. Economies 2018, 6, 20. [CrossRef]

64. Steup, M. Epistemology. In The Stanford Encyclopedia of Philosophy; Zalta, E.N., Ed.; 2008. Available online: https:/ / plato.stanford.edu/archives/win2018/entries/epistemology/ (accessed on 17 February 2019).

65. Rowley, J. The wisdom hierarchy: Representations of the DIKW hierarchy. J. Inf. Sci. 2007, 33, $163-180$. [CrossRef]

66. Fricke, M. The knowledge pyramid: A critique of the DIKW hierarchy. J. Inf. Sci. 2009, 35, 131-142. [CrossRef]

67. Intezari, A.; Pauleen, D. Management wisdom in perspective: Are you virtuous enough to succeed in volatile times? J. Bus. Ethics 2014, 120, 393-404. [CrossRef]

68. Moher, D.; Liberati, A.; Tetzlaff, J.; Altman, D.G.; Group, T.P. Preferred Reporting Items for Systematic Reviews and Meta-Analyses: The PRISMA Statement. PLOS Med. 2009, 6, e1000097. [CrossRef]

69. Siddaway, A. What Is a Systematic Literature Review and How Do I Do One? Available online: https:/ / pdfs. semanticscholar.org/2214/2c9cb17b4baab118767e497c93806d741461.pdf (accessed on 14 February 2019).

70. Bieser, J.C.T.; Hilty, L.M. Assessing Indirect Environmental Effects of Information and Communication Technology (ICT): A Systematic Literature Review. Sustainability 2018, 10, 2662. [CrossRef]

71. Jabareen, Y. Building a Conceptual Framework: Philosophy, Definitions, and Procedure. Int. J. Qual. Methods 2009, 8, 49-62. [CrossRef]

72. Jabareen, Y. A new conceptual framework for sustainable development. Environ. Dev. Sustain. 2008, 10, 197-192. [CrossRef]

73. Jabareen, Y. Towards a Sustainability Education Framework: Challenges, Concepts and Strategies-The Contribution from Urban Planning Perspectives. Sustainability 2012, 4, 2247-2269. [CrossRef]

74. Eizenberg, E.; Jabareen, Y. Social Sustainability: A New Conceptual Framework. Sustainability 2017, 9, 68, doi:10.3390/su9010068. [CrossRef]

75. Brynjolfsson, E.; Hitt, L.M. Beyond the productivity paradox. Commun. ACM 1998, 41, 49-55. [CrossRef]

76. Brynjolfsson, E. The productivity paradox of the new digital economy. Commun. ACM 1993, 36, 67-77.

77. Brynjolfsson, E.; McAfee, A. The Second Machine Age: Work, Progress, and Prosperity in a Time of Brilliant Technologies; WW Norton \& Company: New York, NY, USA, 2014.

78. Polak, P. The productivity paradox: A meta-analysis. Inf. Econ. Policy 2017, 38, 38-54. [CrossRef]

79. Van Ark, B. The productivity paradox of the new digital economy. Int. Prod. Monit. 2016, 31, 3-18.

80. Torfing, J.; Peters, B.G.; Pierre, J.; Sorensen, E. Interactive governance: Advancing the paradigm. Public Adm. 2013, 91, 1071-1082.

81. Ansell, C.; Torfing, J. Handbook on Theories of Governance; Edward Elgar Publishing: Cheltenham, UK, 2016.

82. Gill, S. Critical Perspectives on the Crisis of Global Governance: Reimagining the Future; Palgrave Macmillan: Basingstoke, UK, 2015.

83. Ikenberry, G.J. A Crisis of Global Governance? Curr. Hist. 2010, 109, 315-321.

84. Colatrella, S. In Our Hands Is Placed a Power: Austerity, Worldwide Strike Wave, and the Crisis of Global Governance. Soc. Democr. 2011, 25, 82-106. [CrossRef]

85. Afrasine, L. The Financial Crisis-Global Governance Failure? Rev. Econ. Bus. Stud. 2009, 3, 161-177.

86. Goldbach, R. Global Governance and Regulatory Failure; the Political Economy of Banking; International Political Economy Series; Palgrave Macmillan: Basingstoke, UK, 2015

87. Horvath, A. 'Governance' - In Crisis? a Cross-Disciplinary Critical Review of Three Decades of 'Governance' Scholarship; Centre for Global Higher Education, UCL Institute of Education: London, UK, 2017.

88. Guzzini, S.; Neumann, I.B. (Eds.) The Diffusion of Power in Global Governance; Palgrave Macmillan: London, UK, 2012. [CrossRef]

89. Jordan, A.; Schout, A. The Coordination of the European Union; Oxford University Press: Oxford, UK, 2006. 
90. Kahler, M. (Ed.) Networked Politics: Agency, Power, and Governance; Cornell Studies in Political Economy Y. Ithaca; Cornell University Press: London, UK, 2009.

91. Devi, S.; Khagram, S.; Pang, T. Are Existing Governance Structures Equipped to Deal with Today's Global Health Challenges-Towards Systematic Coherence in Scaling Up. Global Health Governance, Volume II, No. 2. Fall 2008/Spring 2009. Available online: http://ghgj.org/Sridhar\%20Khagram\%20and\%20Pang Are\%20Existing\%20Governance.pdf. (accessed on 20 September 2018).

92. Jessop, B. Capitalism and Its Future: Remarks on Regulation, Government and Governance. Rev. Int. Polit. Econ. 1997, 4, 561-581. [CrossRef]

93. Levi-Faur, D.; Sabel, C.F.; Zeitlin, J. Experimentalist Governance; Oxford University Press: Oxford, UK, 2012.

94. Djelic, M.-L.; Sahlin, K. Reordering the World: Transnational Regulatory Governance and Its Challenges. In The Oxford Handbook of Governance; Oxford University Press: Oxford, UK, 2012.

95. Addy, N.A.; Poirier, A.; Blouin, C.; Drager, N.; Dube, L. Whole of Society Approach for Public Health Policymaking: A Case Study of Polycentric Governance from Quebec, Canada: Whole-of-Society Approach for Public Health Policymaking. Ann. N. Y. Acad. Sci. 2014, 1331, 216-229. [CrossRef]

96. Nagendra, H.; Ostrom, E. Polycentric Governance of Multifunctional Forested Landscapes. Int. J. Commons 2012, 6, 104-133. [CrossRef]

97. McNulty, S.L.; Wampler, B. Participatory Governance. In Emerging Trends in the Social and Behavioral Sciences; Scott, R.A., Kosslyn, S.M., Eds.; John Wiley \& Sons, Inc.: Hoboken, NJ, USA, 2015; pp. 1-14. [CrossRef

98. Eagleton-Pierce, M. The Concept of Governance in the Spirit of Capitalism. Crit. Policy Stud. 2014, 8, 5-21. [CrossRef]

99. De Sousa Santos, B. Governance: Between Myth and Reality. RCCS Ann. Rev. 2009. Available online: https: / /journals.openedition.org/rccsar/95 (accessed on 10 January 2019).

100. Clark, W.C. Sustainability science: A room of its own. Proc. Natl. Acad. Sci. USA 2007, 104, 1737-1738. [CrossRef] [PubMed]

101. Agrawal, A.; Chhatre, A. Against mono-consequentialism: Multiple outcomes and their drivers in social-ecological systems. Glob. Environ. Chang. 2011, 21, 1-3. [CrossRef]

102. Lange, P.; Driessen, P.P.J.; Sauer A.; Bornemann, B.; Burger, P. Governing towards sustainability-conceptualizing modes of governance. J. Environ. Policy Plan. 2013, 15, 403-425. [CrossRef]

103. Liu, J.; Dietz, T.; Carpenter, S.R.; Alberti, M.; Folke, C.; Moran, E.; Pell, A.N.; Deadman, P.; Kratz, T.; Lubchenco, J.; et al. Complexity of Coupled Human and Natural Systems. Science 2007, 317, 1513-1516. [CrossRef]

104. Liu, J.; Dietz, T.; Carpenter, S.R.; Folke, C.; Alberti, M.; Redman, C.L.; Schneider, S.H.; Ostrom, E.; Pell, A.N.; Lubchenco, J.; et al. Coupled Human and Natural Systems. R. Swed. Acad. Sci. 2007, 36, 639-649. [CrossRef]

105. Liu, J.; Hull, V.; Batistella, M.; DeFries, R.; Dietz, T.; Fu, F.; Hertel, T.W.; Izaurralde, R.C.; Lambin, E.F.; Li, S.; et al. Framing sustainability in a telecoupled world. Ecol. Soc. 2013, 18, 26. [CrossRef]

106. Liu, J.; Hull, V.; Carter, N.; Viña, A.; Yang W. Framing Sustainability of Coupled Human and Natural Systems. In Pandas and People; Liu, J., Hull, V., Yang, W., Viña, A., Chen, X., Ouyang, Z., Zhang, H., Eds.; Oxford University Press: Oxford, UK, 2016.

107. Binder, C.; Hinkel, J.; Bots, P.; Pahl-Wostl, C. Comparison of frameworks for analyzing social-ecological systems. Ecol. Soc. 2013, 18. [CrossRef]

108. Ostrom, E. A diagnostic approach for going beyond panaceas. Proc. Natl. Acad. Sci. USA 2007, 104, 15181-15187. [CrossRef]

109. Ostrom, E. A general framework for analyzing sustainability of social-ecological systems. Science 2009, 325, 419-422. [CrossRef]

110. McGinnis, M.; Ostrom, E. Social-ecological system framework: Initial changes and continuing challenges. Ecol. Soc. 2014, 19, 30. [CrossRef]

111. Hinkel, J.; Bots, P.W.G.; Schluter, M. Enhancing the Ostrom social-ecological system framework through formalization. Ecol. Soc. 2014, 19, 51.

112. Díaz, S.; Demissew, S.; Carabias, J.; Joly, C.; Lonsdale, M.; Ash, N.; Larigauderie, A.; Adhikari, J.R.; Arico, S.; Báldi, A.; et al. The IPBES Conceptual Framework connecting nature and people. Curr. Opin. Environ. Sustain. 2015, 14, 1-16. [CrossRef]

113. Dhar, V. Data science and prediction. Commun. ACM 2013, 56, 64-73. [CrossRef] 
114. Blei, D.M; Smyth, P. Science and data science. Proc. Natl. Acad. Sci. USA 2017, 114, 8689-8692. [CrossRef]

115. Hey T. The Fourth Paradigm-Data-Intensive Scientific Discovery. In E-Science and Information Management; Communications in Computer and Information Science; Kurbanoglu, S., Al, U., Erdogan, P.L., Tonta, Y., Uçak, N., Eds.; Springer: Berlin/Heidelberg, Germany, 2012; Volume 317.

116. Kitchin, R. Big Data, new epistemologies and paradigm shifts. Big Data Soc. 2014, 1-12. [CrossRef]

117. Resnyansky, L. Conceptual frameworks for social and cultural Big Data analytics: Answering the epistemological challenge. Big Data Soc. 2019. [CrossRef]

118. Anderson, C. The End of Theory: The Data Deluge Makes the Scientific Method Obsolete. Wired. 2008. Available online: http:/ / www.wired.com/science/discoveries/magazine/16-07/pb_theory (accessed on 17 February 2019).

119. Chen, C.L.P.; Zhang, C.-Y. Data-intensive applications, challenges, techniques and technologies: A survey on Big Data. Inf. Sci. 2014, 275, 314-347. [CrossRef]

120. Sokolovska, A.; Kocarev, L. Integrating Technical and Legal Concepts of Privacy. IEEE Access 2018, 6, 26543-26557 [CrossRef]

121. Simon, J.; Bass, T.; Boelman, V.; Mulgan, G. Digital Democracy: The Tools Transforming Political Engagement; NESTA: Rome, Italy, 2017. Available online: https:/ / www.nesta.org.uk/report/digital-democracy-the-toolstransforming-political-engagement/ (accessed on 14 January 2019).

122. Magna Carta for the Web. Available online: http:/ / democracyos.org/ (accessed on 10 January 2019).

123. Learn More About the D21 Solution for Long-Term Participation, Taylored for the 21st Century. Available online: https: / / www.d21.me/en/ (accessed on 10 January 2019).

124. Democracy 21 Is Dedicated to Making Democracy Work for All Americans. Available online: http://www. democracy21.org/ (accessed on 5 January 2019).

125. Dennis, L. From e-government to we-government: Defining a typology for citizen coproduction in the age of social media. Gov. Inf. Q. 2012, 29, 446-454.

126. Liu, S.M.; Kim, Y. Special issue on internet plus government: New opportunities to solve public problems? Gov. Inf. Q. 2018, 35, 88-97. [CrossRef]

127. Ben Milligan, B.; Michelle O'Keeffe, M. Global governance of resources and implications for resource efficiency in Europe. Ecol. Econ. 2019, 155, 46-58. [CrossRef]

128. Harris, P.G. (Ed.) Routledge Handbook of Global Environmental Politics; Routledge: Abingdon, UK, 2016.

129. Hunter, D.; Salzman, J.; Zaelke, D. International Environmental Law and Policy, 5th ed.; Foundation Press: New York, NY, USA, 2015.

130. Newig, J.; Fritsch, O. Environmental Governance: Participatory, Multi-level and Effective? Environ. Policy Gov. 2009, 19, 197-214. [CrossRef]

131. Benvenisti, E. Sharing Transboundary Resources: International Law and Optimal Resource Use; Cambridge University Press: Cambridge, UK, 2002.

132. Williams, B. Ethics and the Limits of Philosophy; Fontana Press: London, UK, 1985.

133. Putnam, H. The Collapse of the Fact/Value Dichotomy and Other Essays; Harvard University Press: Cambridge, MA, USA, 2002.

134. Roberts, D. Thick concepts. Philos. Compass 2013, 8, 677-688. [CrossRef]

135. United Nations (UN). Agenda 21; United Nations: New York, NY, USA, 1992.

136. United Nations (UN). United Nations Millennium Declaration; Resolution 55/2, Adopted by the General Assembly; United Nations: New York, NY, USA, 2000.

137. United Nations (UN). The Future We Want; Resolution 66/288, adopted by the General Assembly; United Nations: New York, NY, USA, 2012.

138. Kant, I. Logic; Dover Publications: New York, NY, USA, 1974.

139. Pincet, A.; Okabe, S.; Pawelczyk, M. Linking Aid to Sustainable Development Goals: A Machine Learning Approach; OECD Development Cooperation Working Papers; OECD Publishing: Paris, France, 2019.

140. Dupriez, O. An Empirical Comparison of Machine Learning Classification Algorithms; World Bank: Washington, DC, USA, 2008. Available online: http://pubdocs.worldbank.org/en/666731519844418182/PRT-ODpresentation-V2.pdf (accessed on 18 February 2019).

141. Goldblatt, R.; Stuhlmacher, M.F.; Tellman, B.; Clinton, N.; Hanson, G.; Georgescu, M.; Wang, C.; Serrano-Candela, F.; Khandelwal, A.K.; Cheng, W.H.; et al. Using Landsat and nighttime lights for supervised pixel-based image classification of urban land cover. Remote Sens. Environ. 2017, 205, 253-275. [CrossRef] 
142. Blumenstock, J. Don't forget people in the use of big data for development. Nature 2018, 561/7722, $170-172$. [CrossRef] [PubMed]

143. Ostrom, E. Governing the Commons: The Evolution of Institutions for Collective Action; Cambridge University Press: Cambridge, UK, 1990.

144. Crawford, S.E.S.; Ostrom, E. A grammar of institutions. Am. Polit. Sci. Rev. 1995, 89, 582-600. [CrossRef]

145. Ohmae, K. The rise of the region state. In Foreign Affairs; Council on Foreign Relations: New York, NY, USA, 1993; pp. 78-87.

146. Barber, B.B. Strong Democracy: Participatory Politics for a New Age; Univ of California Press: Berkeley, CA, USA, 2003

147. Taleb, N.N. Antifragile: Things That Gain From Disorder; Random House: New York, NY, USA, 2012.

148. Bouteligier, S. Cities break new ground. Broker 2009, 17, 13-21.

149. Oxford University Press. World Commission on Environment and Development: Our Common Future; Oxford University Press: Oxford, UK, 1987.

150. Betsill, M.; Bulkeley, H. Cities and the multilevel governance of global climate change. Glob. Gov. 2006, 12, 141-159. [CrossRef]

151. Toly, N.J. Transnational municipal networks in climate politics: From global governance to global politics. Globalizations 2008, 5, 341-356. [CrossRef]

152. Kern, K.; Bulkeley, H. Cities, Europeanization and multi-level governance: Governing climate change through transnational municipal networks. J. Common. Mark. Stud. 2009, 47, 309-332. [CrossRef]

153. Lee, T. Global cities and transnational climate change networks. Glob. Environ. Polit. 2013, 13, $108-127$. [CrossRef]

154. Bulkeley, H.; Betsill, M. Rethinking sustainable cities: Multilevel governance and the 'urban' politics of climate change. Environ. Polit. 2005, 14, 42-63. [CrossRef]

155. Bulkeley, H.; Betsill, M. Revisiting the urban politics of climate change. Environ. Polit. 2013, 22, $136-154$. [CrossRef]

156. Fuhr, H.; Hickmann T.; Kern, K. The role of cities in multi-level climate governance: Local climate policies and the $1.5^{\circ} \mathrm{C}$ target. Curr. Opin. Environ. Sustain. 2018, 30, 1-6. [CrossRef]

157. Campbell, T.; Fuhr, H. (Eds.) Leadership and Innovation in Subnational Government: Case Studies from Latin America; The World Bank: Washington, DC, USA, 2004.

158. Rosenzweig, C.; Solecki, W.; Hammer, S.A.; Mehrotra, S. Cities lead the way in climate-change action. Nature 2010, 467, 909-911. [CrossRef]

159. Roger, C.; Hale, T; Andonova, L. The comparative politics of transnational climate governance. Int. Interact. 2017, 43, 1-25. [CrossRef]

160. Fenton, P.; Gustafsson, S. Moving from high-level words to local action-Governance for urban sustainability in municipalities. Curr. Opin. Environ. Sustain. 2017, 26-27, 129-133. [CrossRef]

161. Corr, P.; Plagno, A. Behavioral Economics: The Basics; Taylor \& Francis: London, UK, 2019.

162. Thaler, R.H. Behavioral Economics: Past, Present and Future. Available online: https://ssrn.com/abstract= 2790606 (accessed on 27 December 2018).

163. Lawrence, E. Blume and David Easley, "Rationality". In The New Palgrave Dictionary of Economics, 2nd ed.; Durlauf, S.N., Blume, L.E., Eds.; Palgrave Macmillan: Basingstoke, UK, 2008.

164. Ostrom, E. Beyond markets and states: Polycentric governance of complex economic systems. Am. Econ. Rev. 2010, 100, 641-672. [CrossRef]

165. Kosinski, M.; Stillwell, D.; Graepel, T. Private traits and attributes are predictable from digital records of human behavior. Proc. Natl. Acad. Sci. USA 2013, 110, 5802-5805. [CrossRef]

166. MacIntyre, A. A Short History of Ethics, 2nd ed.; Routledge: London, UK, 1998.

167. Noorman, M. Computing and Moral Responsibility. In The Stanford Encyclopedia of Philosophy; Zalta, E.N., Ed.; Spring: Berlin, Germany, 2018. Available online: https:/ / plato.stanford.edu/archives/spr2018/entries/ computing-responsibility/ (accessed on 18 February 2019).

168. Zwitter, A. Big Data ethics. Big Data Soc. 2014, 1-6. [CrossRef]

169. Floridi, L.; Taddeo, M. What is data ethics? Philos. Trans. R. Soc. A 2016, 374. [CrossRef] [PubMed]

170. Richards, N.M.; King, J. Big Data Ethics. Wake For. Law Rev. 2014, 393, 409.

171. Floridi, L. Soft Ethics and the Governance of the Digital. Philos. Technol. 2018, 31, 1-8. [CrossRef] 
172. Christman, J. Autonomy in Moral and Political Philosophy. In The Stanford Encyclopedia of Philosophy; Zalta, E.N., Ed.; Spring: Berlin, Germany, 2018; Available online: https:/ / plato.stanford.edu/archives/spr2018/ entries/autonomy-moral/ (accessed on 10 January 2019).

173. Dworkin, G. Paternalism. In The Stanford Encyclopedia of Philosophy; Zalta, E.N., Ed.; Spring: Berlin, Germany, 2017. Available online: https:/ / plato.stanford.edu/archives/win2017/entries/paternalism/ (accessed on 10 January 2019).

174. Thaler, R.H.; Sunstein, C.R. Nudge: Improving Decisions About Health, Wealth, and Happiness; Yale University Press: New Haven, CT, USA, 2008,

175. Acquisti, A.; Adjerid, I.; Balebako, R.; Brandimarte, L.; Cranor, L.; Komanduri, S.; Leon, P.; Sadeh, N.; Schaub, F.; Sleeper, M.; et al. Nudges for Privacy and Security: Understanding and Assisting Users' Choices Online. ACM Comput. Surv. 2017, 50, 44. [CrossRef]

176. Baeten, G. The tragedy of the highway: Empowerment, disempowerment and the politics of sustainability discourses and practices. Eur. Plan. Stud. 2000, 8, 69-86. [CrossRef]

177. Sachs, W. Global ecology and the shadow of development. In Global Ecology: A New Arena of Political Conflict; Sachs, W., Ed.; Zed: London, UK, 1993; pp. 3-20.

178. Liu, J. Integration across a metacoupled world. Ecol. Soc. 2017, 22, 29.10.5751/ES-09830-220429. [CrossRef]

179. Carlisle, K.; Gruby, R.L. Polycentric systems of governance: A theoretical model for the commons. Policy Stud. J. 2017. [CrossRef]

180. Oberlack, C; Boillat, S.; Brönnimann, S.; Gerber, J.-D.; Heinimann, A.; Speranza, C.I.; Messerli, P.; Rist, S.; Wiesmann, U. Polycentric governance in telecoupled resource systems. Ecol. Soc. 2018, 23, 16.

181. Zdraveski, V.; Mishev, K.; Trajanov, D.; Kocarev, L. ISO-Standardized Smart City Platform Architecture and Dashboard. IEEE Pervasive Comput. 2017, 16, 35-43. [CrossRef]

182. Muhar, A.; Raymond, C.M.; van den Born, R.J.G.; Bauer, N.; Böck, K.; Braito, M. A model integrating social-cultural concepts of nature into frameworks of interaction between social and natural systems. J. Environ. Plan. Manag. 2018, 61, 756-777. [CrossRef]

183. Kelly, R.A.; Jakeman, A.J.; Barreteau, O.; Borsuk, M.E.; ElSawah, S.; Hamilton, S.H.; Henriksen, H.J.; Kuikka, S.; Maier, H.R.; Rizzoli, A.E.; et al. Selecting among five common modelling approaches for integrated environmental assessment and management. Environ. Model. Softw. 2013, 47, 159-181. [CrossRef]

184. Fraternali, P.; Castelletti, A.; Soncini-Sessa, R.; Vaca Ruiz, C.; Rizzoli, A.E. Putting humans in the loop: Social computing for water resources management. Environ. Model. Softw. 2012, 37, 68-77. [CrossRef]

185. Haapasaari, P.; Mäntyniemi, S.; Kuikka, S. Baltic Herring Fisheries management: Stakeholder views to frame the problem. Ecol. Soc. 2012, 17, 36. [CrossRef]

186. van Vuuren, D.P.; Stehfest, E.; Gernaat, D.E.H.J.; Doelman, J.C.; den Berg, M.; Harmsen, M.; de Boer, H.S.; Bouwman, L.F.; Daioglou, V.; Edelenbosch, O.Y.; et al. Energy, land-use and greenhouse gas emissions trajectories under a green growth paradigm. Glob. Environ. Chang. 2017, 42, 237-250. [CrossRef]

187. Fricko, O.; Havlik, P.; Rogelj, J.; Klimont, Z.; Gusti, M.; Johnson, N.; Kolp, P.; Strubegger, M.; Valin, H.; Amann, M.; et al. The marker quantification of the Shared Socioeconomic Pathway 2: A middle-of-the-road scenario for the 21st century. Glob. Environ. Chang. 2017, 42, 251-267. [CrossRef]

188. Fujimori, S.; Hasegawa, T.; Masui, T.; Takahashi, K.; Herran, D.S.; Hancheng Dai, H.; Hijioka, Y.; Kainuma, M. SSP3: AIM implementation of Shared Socioeconomic Pathways. Glob. Environ. Chang. 2017, 42, 268-283. [CrossRef]

189. Calvin, K.; Bond-Lamberty, B.; Clarke, L.; Edmonds, J.; Eom, J.; Hartin, C.; Kim, S.; Kyle, P.; Link, R.; Moss, R.; et al. The SSP4: A world of deepening inequality. Glob. Environ. Chang. 2017, 42, 284-296. [CrossRef]

190. Kriegler, E.; Bauer, N.; Popp, A.; Humpenoder, F.; Leimbach, M.; Strefler, J.; Baumstark, L.; Bodirsky, B.L.; Hilaire, J.; Klein, D.; et al. Fossil-fueled development (SSP5): An energy and resource intensive scenario for the 21st century. Glob. Environ. Chang. 2017, 42, 297-315. [CrossRef]

191. Emmerling J.; Drouet, L.; Reis, L.; Bevione, M.; Berger, L.; Bosetti, V.; Carrara, S.; De Cian, E.; de d'Aertrycke, G.M.; Longden, T.; et al. The WITCH 2016 Model_Documentation And Implementation of the Shared Socioeconomic Pathways; FEEM Working Paper 42.2016; 2016. Available online: https:/ / papers.ssrn.com/sol3 / papers.cfm? abstract_id $=2800970$ (accessed on 10 January 2019)

192. Weiss T.G.; Thakur, R.C. Global Governance and the UN: An Unfinished Journey; Indiana University Press: Bloomington, IN, USA, 2010. 
193. Kanie, N.; Biermann, F. (Eds.) Governing Through Goals: Sustainable Development Goals as Governance Innovation; MIT Press: Cambridge, MA, USA, 2017

194. Biermann, F.; Kanie, N.; Kim, R.E. Global governance by goal-setting: The novel approach of the UN Sustainable Development Goals. Curr. Opin. Environ. Sustain. 2017, 26-27, 26-31. [CrossRef]

195. Chasek, P.S.; Wagner, L.M. Breaking the mold: A new type of multilateral sustainable development negotiation. Int. Environ. Agreem. 2016, 16, 397-413. [CrossRef]

196. Gellers, J.C. Crowdsourcing global governance: Sustainable Development Goals, civil society, and the pursuit of democratic legitimacy. Int. Environ. Agreem. 2016, 16, 415-432. [CrossRef]

197. Sachs, J.D. From Millennium Development Goals to Sustainable Development Goals. Lancet 2012, 379, 2206-2211. [CrossRef]

198. Steelman, T. Adaptive governance. In Handbook on Theories of Governance; Ansell, C., Torfing, J., Eds.; Edward Elgar Publishing: Cheltenham, UK, 2016; pp. 538-550.

199. Hong, S.; Lee, S. Adaptive governance and decentralization: Evidence from regulation of the sharing economy in multi-level governance. Gov. Inf. Q. 2018, 35, 299-305. [CrossRef]

200. Wang, C.; Medaglia, R.; Zheng, L. Towards a typology of adaptive governance in the digital government context: The role of decision-making and accountability. Gov. Inf. Q. 2018, 35, 306-322. [CrossRef]

201. Dietz, T.; Ostrom, E.; Stern, P.C. The struggle to govern the commons. Science 2003, 302, 1902-1912. [CrossRef] [PubMed]

202. Keast, R. Network governance. In Handbook on Theories of Governance; Ansell, C., Torfing, J., Eds.; Edward Elgar Publishing: Cheltenham, UK, 2016; pp. 442-453.

203. Provan, K.G.; Kenis, P. Modes of Network Governance: Structure, Management, and Effectiveness. J. Public Adm. Res. Theory 2008, 18, 229-252. [CrossRef]

204. Raab, J.; Mannak R.S.; Cambré B. Combining structure, governance, and context: A configurational approach to network effectiveness. J. Public Adm. Res. Theory 2015, 25, 479-511. [CrossRef]

205. Considine, M.; Lewis, J.; Alexander, D. Networks, Innovation and Public Policy: Politicians, Bureaucrats and the Pathways to Change inside Government; Palgrave Macmillan: Houndmills, UK, 2009.

206. Klijn, E.H.; Steijn, B.; Edelenbos, J. The impact of network management on outcomes in governance networks. Public Adm. 2010, 88, 1063-1082. [CrossRef]

207. Purdy, J. A framework for assessing power in collaborative governance processes. Public Adm. Rev. 2012, 72, 409-417. [CrossRef]

208. Gash, A. Collaborative governance. In Handbook on Theories of Governance; Ansell, C., Torfing, J., Eds.; Edward Elgar Publishing: Cheltenham, UK, 2016; pp. 454-467,

209. Johnston, E.W.; Hicks, D.; Ning, N.; Auer, J.C. Managing the inclusion process in collaborative governance. J. Public Adm. Res. Theory 2010, 21, 699-721. [CrossRef]

210. Koppell, J.G.S. Pathologies of accountability: ICANN and the challenge of multiple accountabilities disorder. Public Adm. Rev. 2005, 65, 94-108. [CrossRef]

211. Considine, M. The End of the Line? Accountable Governance in the Age of Networks, Partnerships, and Joined-Up Services. Governance 2002, 15, 21-40. [CrossRef]

212. Bovens, M.; Goodin, R.E.; Schillemans, T. The Oxford Handbook of Public Accountability; Oxford University Press: Oxford, UK, 2014.

213. Thomann, E.; Hupe, P.; Sager, F. Serving many masters: Public accountability in private policy implementation. Governance 2018, 31, 299-319. [CrossRef]

214. Swan, M. Blockchain; O’Reilly Media, Inc.: Sebastopol, CA, USA, 2015.

215. DLT, Smart Contract Engine. Available online: https://www.hyperledger.org/projects/fabric (accessed on 5 January 2019).

216. Abbott, K.W.; Genschel, P.; Snidal, D.; Zangl, B. (Eds.) International Organizations as Orchestrators; Cambridge University Press: Cambridge, UK, 2015.

217. Visvizi, A.; Lytras, M.D. Rescaling and refocusing smart cities research: From mega cities to smart villages. J. Sci. Technol. Policy Manag. 2018, 9, 134-145. [CrossRef]

218. Visvizi, A.; Lytras, M.D.; Damiani, E.; Mathkour, H. Policy making for smart cities: Innovation and social inclusive economic growth for sustainability. J. Sci. Technol. Policy Manag. 2018, 9, 126-133. [CrossRef] 
219. Sridhar, D. Making the SDGs useful: A Herculean task. Lancet 2016, 388, 1453-1455. [CrossRef]

220. Steffen, W.; Broadgate, W.; Deutsch, L.; Gaffney, O.; Ludwig, C. The trajectory of the Anthropocene: The Great Acceleration. Anthr. Rev. 2015, 2, 81-98. [CrossRef] 